\title{
Efficacy of chloroquine and hydroxychloroquine in treating COVID-19 infection: a meta-review of systematic reviews and an updated meta-analysis
}

Tawanda Chivese ${ }^{1}$, Omran A. H. Musa ${ }^{1}$, George Hindy ${ }^{1}$, Noor Al-Wattary ${ }^{1}$, Saif Badran $^{1,2}$, Nada Soliman ${ }^{3}$, Ahmed T. M. Aboughalia ${ }^{3}$, Joshua T. Matizanadzo ${ }^{4}$, Mohamed M. Emara ${ }^{5,6}$, Lukman Thalib ${ }^{7}$, Suhail A. R. Doi ${ }^{1}$

1. Department of Population Medicine, College of Medicine, QU Health, Qatar University, Doha, Qatar

2. Hamad General Hospital, Doha, Qatar.

3. College of Medicine, QU Health, Qatar University, Doha, Qatar

4. Brighton and Sussex Medical School, United Kingdom

5. Basic Medical Sciences Department, College of Medicine, QU Health, Qatar University, Doha, Qatar

6. Biomedical and Pharmaceutical Research Unit, QU Health, Qatar University, Doha, Qatar

7. Department of Biostatistics, Faculty of Medicine, Istanbul Aydin University, Istanbul, Turkey

${ }^{*}$ Corresponding author:

Tawanda Chivese

Department of population medicine, College of medicine, QU Health, Qatar

University, Doha, Qatar

Email: tchivese@qu.edu.qa

Tel: +97444037831 


\section{Abstract}

\section{Objective}

To synthesize findings from systematic reviews and meta-analyses on the efficacy and safety of chloroquine (CQ) and hydroxychloroquine (HCQ) with or without Azithromycin for treating COVID-19, and to update the evidence using a meta-analysis.

\section{Methods}

A comprehensive search was carried out in electronic databases for systematic reviews, meta-analyses and experimental studies which investigated the efficacy and safety of $\mathrm{CQ}, \mathrm{HCQ}$ with or without Azithromycin to treat COVID-19. Findings from the reviews were synthesised using tables and forest plots and the quality effect model was used for the updated meta-analysis. The main outcomes were mortality, the need for intensive care services, disease exacerbation, viral clearance and occurrence of adverse events.

\section{Results}

Thirteen reviews with 40 primary studies were included. Two meta-analyses reported a high risk of mortality, with ORs of 2.2 and 3.0, and the two others found no association between $\mathrm{HCQ}$ and mortality. Findings from two meta-analyses showed that HCQ with Azithromycin increased the risk of mortality, with similar ORs of 2.5. The updated metaanalysis of experimental studies showed that the drugs were not effective in reducing mortality (RR 1.1, 95\% Cl 1.0-1.3, $\mathrm{I}^{2}=0.0 \%$ ), need for intensive care services (OR 1.1, $95 \% \mathrm{Cl} 0.9-1.4, \mathrm{I}^{2}=0.0 \%$ ), virological cure (OR $1.5,95 \% \mathrm{Cl} 0.5-4.4, \mathrm{I}^{2}=39.6 \%$ ) or disease exacerbation (OR $1.2,95 \% \mathrm{Cl} 0.3-5.9, \mathrm{I}^{2}=31.9 \%$ ) but increased the odds of adverse events (OR 12,3, 95\% Cl 2.5-59.9, $\left.\right|^{2}=76.6 \%$ ).

\section{Conclusion}

There is conclusive evidence that $\mathrm{CQ}$ and $\mathrm{HCQ}$, with or without Azithromycin are not effective in treating COVID-19 or its exacerbation. 


\section{Registration}

PROSPERO: CRD42020191353

\section{Key Words}

COVID-19, hydroxychloroquine, chloroquine, efficacy, mortality, ICU, virological cure, disease worsening, adverse events

\section{Introduction}

The severe acute respiratory syndrome coronavirus 2 (SARS-CoV2) is currently known to be among one of the most contagious viruses in the history of pathogens (1). This novel human coronavirus was first reported in Wuhan in December 2019 and has since spread from person to person in an efficient and sustained way to cause a global pandemic, with the disease named Coronavirus Disease-19 (COVID-19) (1). Although the disease is largely controlled in China, where it was first reported, the number of cases and deaths continue to increase globally, with the highest numbers of confirmed cases in the USA, Brazil and India (2). The availability of vaccines has resulted in the relaxation of restrictive measures in many countries. However, the vaccinations have been slow in the low-and-middle income countries and the morbidity and mortality from COVID-19 are expected to continue increasing as successive waves driven by variants of the SARS-CoV-2 virus affect many countries (3-5). This continued increase in morbidity and mortality from COVID-19 warrants the need to investigate effective therapies.

Of several therapeutic drugs that have been suggested, chloroquine (CQ), an antimalarial drug in the class of 4-aminoquinolones with anti-inflammatory, antiviral and anti-thrombolytic properties, and its derivative, hydroxychloroquine (HCQ) have been repurposed and are being used widely for the treatment of COVID-19 $(6,7)$. CQ and HCQ are antimalarials and also used as disease-modifying antirheumatic drugs (DMARDs) (8). There are several mechanisms which have been suggested for the expected effect of the two drugs against viruses in general and SARS-COV-2 in particular. One of these mechanisms is based on inhibiting the ability of the virus to enter the cell. SARS-COV-2 harbours a spike (S) protein, which is considered a crucial element in the virus replication cycle as it binds to angiotensin-converting enzyme 2 (ACE2) expressed in 
medRxiv preprint doi: https://doi.org/10.1101/2020.07.28.20164012; this version posted July 9, 2021. The copyright holder for this preprint (which was not certified by peer review) is the author/funder, who has granted medRxiv a license to display the preprint in perpetuity. It is made available under a CC-BY-NC-ND 4.0 International license .

the lungs of the host cell receptor (9). The antiviral effect of both CQ and HCQ is thought to be through their ability to interfere with the glycosylation of ACE2 and thus prevent the proper binding of the S protein (8). Moreover, virus entry occurs through receptor-mediated endocytosis, which needs an acidic $\mathrm{PH}$ to complete the fusion and deliver the viral genome into the cell. Both $\mathrm{CQ}$ and $\mathrm{HCQ}$ are weak bases and thought to inhibit this process that the SARS COV-2 virus needs for replication (8). Apart from their direct antiviral properties, CQ and HCQ also seem to have immune-modulatory effects which help to reduce over-activation of the immune system from COVID-19 (8). HCQ has been used more frequently than CQ in treating COVID-19 as it has been reported to be more potent in vitro (10), can be used in higher doses for a longer time with a lower risk of adverse events compared to $C Q$ and is more widely available $(6,11)$. Further, both drugs are relatively cheap, and their use in the treatment of COVID19 is based on promising results from in vitro studies $(10,12)$ and some observational studies (13). Repurposing the drugs for use in treating COVID-19 has been easy as the drugs are already in use for the treatment of malaria, are cheap and have been thought to have a relatively safe profile $(6,14)$. Due to the above reasons and the unprecedented situation and the urgency to curb the COVID-19 pandemic, CQ and HCQ have been approved, on a fast track basis, by the United States Food and Drug Administration and other regulatory bodies, despite the lack of good quality evidence of their efficacy and safety $(15,16)$. Consequently, more than 80 trials of the two drugs are either ongoing or completed and it is necessary to evaluate the evidence so clinicians and regulatory bodies can make informed decisions on the use of these drugs for the treatment of COVID-19 infection.

Initial reports suggested that HCQ was effective in the treatment of COVID-19 associated pneumonia (17) and that HCQ in combination with the second-generation macrolide antibiotic, Azithromycin, resulted in a lower fatality (18), and $93 \%$ viral clearance of COVID-19, by day 8 (13). However, subsequent findings from both observational studies and clinical trials have been contradictory (19-22). Further, although the two drugs are relatively safe in the treatment of malaria, concerns have been raised about the risk of adverse events associated with their use when treating 
medRxiv preprint doi: https://doi.org/10.1101/2020.07.28.20164012; this version posted July 9, 2021. The copyright holder for this preprint (which was not certified by peer review) is the author/funder, who has granted medRxiv a license to display the preprint in perpetuity. It is made available under a CC-BY-NC-ND 4.0 International license .

COVID-19 (23). The RECOVERY trial (24), one of the largest trials to-date investigating the optimal treatment for COVID-19, issued a statement that they found no differences in mortality between participants on HCQ and those on usual care, and subsequently stopped the HCQ arm of the trial. In a similar move, the World Health Organization stopped the HCQ arm of the SOLIDARITY trial (23), citing the lack of efficacy from their interim analysis of the U.K. RECOVERY trial, the French DisCoVeRy trial (25) and an unnamed Cochrane review (26). Before the stopping of the RECOVERY and SOLIDARITY trials, the largest observational study to date, a multinational cohort study of 96,000 participants, had previously reported a 6-to-8-fold increase in the mortality associated with $\mathrm{CQ}$ or HCQ, with or without macrolides (27). However, the study (27) was subsequently retracted due to concerns over the veracity of the data and its analysis, leaving some degree of uncertainty in its wake.

Several systematic reviews and meta-analyses investigating the efficacy and the safety of $\mathrm{CQ}$ and $\mathrm{HCQ}$ have been published (28-32). Similar to the primary studies, systematic reviews and meta-analyses have presented contradictory findings. A key issue that made it difficult to have conclusive results on the efficacy of $C Q$ and HCQ with or without the macrolide antibiotics is that clinical trials were few, small and poorly designed. Most of the existing systematic reviews have therefore carried out metaanalyses combining data from observational and experimental studies without accounting for the quality of included studies. Several clinical trials, with acceptable quality, are now available. Therefore, it has become necessary to synthesize all available evidence to provide the best evidence-based assessment on the efficacy and safety of both $\mathrm{CQ}$ and $\mathrm{HCQ}$, with or without macrolide antibiotics, in the treatment of COVID-19 infection. In this respect, we conducted this umbrella review with two broad aims; (1) to assess the efficacy and safety of each of HCQ and CQ, with or without Azithromycin in the treatment of COVID-19 by assessing the evidence from existing systematic reviews and meta-analyses, and (2) to carry out an updated meta-analysis of the existing experimental studies to assess the efficacy of these drugs. 


\section{Methods}

\section{Study Design}

This study protocol is registered on PROSPERO (CRD42020191353). This study had two components; an overview of all existing systematic reviews and meta-analyses and an updated meta-analysis of all eligible experimental studies that investigated the efficacy of either $\mathrm{CQ}$ or $\mathrm{HCQ}$ with or without macrolide antibiotics in the treatment of COVID-19. The design of this overview followed the Preferred reporting items for overviews of systematic reviews including harms checklist guidelines (PRIO-harms) (33). The updated meta-analysis was carried out according to the Preferred Reporting Items for Systematic Review and Meta-Analysis (PRISMA) (34).

\section{Search strategy}

We conducted electronic searches for all experimental studies, systematic reviews and meta-analyses on the efficacy and safety of $C Q$ and HCQ for the treatment of COVID19 up to the $3^{\text {rd }}$ of June 2020. We searched for studies in the following electronic databases; Cochrane Database of Systematic Reviews (CDSR) (The Cochrane Library), Cochrane Central Register of Controlled Trials (CENTRAL), the China Academic Journals Full Text Database, EMBASE and MEDLINE through PubMed, the Database of Abstracts of Reviews of Effectiveness (DARE), Scopus, Web of Science, $\mathrm{CINAHL}$, and the databases of preprints. We hand-searched the databases of preprints (medrxiv.org/ and https://www.biorxiv.org/) and the websites for the World Health Organization Solidarity Trial and the U.K. Recovery Trial. We manually searched all references of all included studies and carried out a citation search of all included systematic reviews. We identified experimental studies from the included reviews and from the database searches. The top 20 similar articles citation search of all included studies was performed on Pubmed to retrieve studies that might have been missed in the original electronic search.

We used the following search terms for chloroquine and hydroxychloroquine; "chloroquine" OR "hydroxychloroquine" OR "CQ" OR "HCQ". We used the following 
medRxiv preprint doi: https://doi.org/10.1101/2020.07.28.20164012; this version posted July 9, 2021. The copyright holder for this preprint (which was not certified by peer review) is the author/funder, who has granted medRxiv a license to display the preprint in perpetuity. It is made available under a CC-BY-NC-ND 4.0 International license .

search terms for COVID19 infection; "COVID19" OR "Coronavirus" OR "novel coronavirus" OR "SARS-CoV-2" OR "COVID" OR "COVID-19". The following search terms were used for the study design; "clinical study", "clinical trial”, "trial", "RCT", "controlled trial", "randomized controlled trial", "meta-analysis", "rapid review", "review", "systematic reviews". All searches had no limitations on language or location but were limited to studies published during the year 2020. Keywords and Medical Subject Headings (Mesh) were used for searches for COVID19, SARS-CoV2, chloroquine and hydroxychloroquine. The full electronic search strategy is given in Appendix 1 (Supplementary Document S1).

\section{Eligibility}

We included systematic reviews and meta-analyses which compared the efficacy and/or safety of $\mathrm{HCQ}$ or $\mathrm{CQ}$. Such reviews should either have a minimum of two clinical studies comparing $\mathrm{HCQ}$ or $\mathrm{CQ}$ with or without Azithromycin to any other standard treatments, including placebo. Participants in the included index primary studies should have had confirmed COVID-19, regardless of age or the severity of illness. Reviews were excluded if they were literature reviews, did not include at least two eligible primary studies and if their main scope was on prophylaxis. The updated meta-analysis only included experimental studies which investigated the efficacy of either $C Q, H C Q$ or without Azithromycin for the treatment of COVID-19. Studies where participants were diagnosed using symptoms were excluded as symptoms have been shown to have poor diagnostic accuracy (35). Observational studies and any studies without control groups were excluded. Studies on animals and in-vitro studies were also excluded. In the case that studies were duplicates, either the study with the most data was used and the other excluded or both studies were combined. Studies were included if the intervention included either $\mathrm{CQ}$ or HCQ alone or with Azithromycin in any dose combinations and any length of administration. Due to the heterogeneous nature of COVID-19 treatments in different countries and different disease severity categories, any studies that had control groups that did not include either CQ or HCQ were acceptable for inclusion in this overview and meta-analysis. Studies were also included irrespective of either the 
medRxiv preprint doi: https://doi.org/10.1101/2020.07.28.20164012; this version posted July 9, 2021. The copyright holder for this preprint (which was not certified by peer review) is the author/funder, who has granted medRxiv a license to display the preprint in perpetuity. It is made available under a CC-BY-NC-ND 4.0 International license .

severity of disease of included participants or the setting (i.e. either hospital-based or community or both).

\section{Data extraction}

Search results were uploaded on to the Rayyan systematic review management platform (https://www.rayyan.ai/) where 2 authors blindly screened titles and abstracts. Conflicts were discussed and resolved by consensus between authors. The full text of potentially relevant articles were screened against eligibility criteria for the final inclusion.

For each study, two authors independently extracted data and assessed quality. The data extracted from the reviews included; type of review (systematic review or metaanalysis), date of publication or submission to the preprint servers, countries with data included in the review, scope of the review, the number and type of index studies included, tools used to assess the risk of bias, risk of bias summary, main comparisons, total participants, mean age, outcomes measured and pooled measures of effect, statistics for heterogeneity, the review conclusion and limitations. Additional data included the number of and citations of all included primary studies in the review. The primary studies were further categorised as either experimental or observational, first based on their classification in the parent review and later after an independent assessment by two authors. All experimental studies identified from the assessment were considered for inclusion in the updated meta-analysis.

Data extracted from experimental studies included study design (RCT or quasi-RCT), intervention (whether CQ or HCQ with or without Azithromycin), dosage, route of administration, control treatment description, any co-interventions, setting (community setting or hospital), the country where study carried out, proportions with severe sickness, proportions with comorbidities, mean age, gender distribution, and total with each out outcome in the intervention and control groups. 
medRxiv preprint doi: https://doi.org/10.1101/2020.07.28.20164012; this version posted July 9, 2021. The copyright holder for this preprint (which was not certified by peer review) is the author/funder, who has granted medRxiv a license to display the preprint in perpetuity. It is made available under a CC-BY-NC-ND 4.0 International license .

\section{Outcomes}

Due to the heterogeneous nature of the outcomes assessed in different systematic reviews, meta-analyses and primary studies, we grouped the outcomes into four main groups. The primary outcome was mortality assessed as all-cause mortality. Secondary outcomes were disease exacerbation, virological cure, adverse events and included a composite outcome that combined the events of any transfer to the intensive care unit (ICU), any need for intubation or any need for mechanical ventilation. Disease worsening was defined as any form of symptom worsening such as the need for oxygen, dyspnoea, hospitalization in the case of community-based studies. The virological cure was defined as a negative PCR any time after commencement of treatment. Safety was assessed as the occurrence of the known adverse events of $C Q$ or HCQ or Azithromycin. These adverse events included gastric side effects such as diarrhoea and vomiting, ventricular tachycardia possibly because of QTc prolongation and headache, blurred vision and rash.

\section{Assessment of study quality}

Two authors independently assessed the quality of each included review using the Assessing the Methodological Quality of Systematic Reviews (AMSTAR) tool (36). Each review had a maximum score of 11 if the methodological quality is good and zero if the methodological quality is poor. Any disagreements were resolved by discussion between the authors.

For the experimental studies, the MethodologicAI STandard for Epidemiological Research (MASTER) scale (37) was used to assess the methodological quality of studies across safeguards listed within 7 standards. The 7 standards assessed were; equal recruitment, equal retention, equal ascertainment, equal implementation, equal prognosis, sufficient analysis and temporal precedence (38). A kappa interrater agreement was calculated for each study and the quality safeguard counts averaged if the Kappa was at least 0.70. Where the Kappa was below 0.7, the authors resolved disagreements by discussion or by referring to a third assessor if they did not resolve. The quality counts were used to rank studies for inclusion in a quality adjusted metaanalysis. 
medRxiv preprint doi: https://doi.org/10.1101/2020.07.28.20164012; this version posted July 9, 2021. The copyright holder for this preprint (which was not certified by peer review) is the author/funder, who has granted medRxiv a license to display the preprint in perpetuity. It is made available under a CC-BY-NC-ND 4.0 International license .

\section{Synthesis of findings}

Synthesis of findings from different reviews was done using a combination of a structured summary of findings from the reviews and presentation in forest plots (39). A table with the findings of each review for each outcome was presented. For outcomes were several meta-analyses were available, forest plots were used to show the magnitude of the effect, the $95 \%$ confidence intervals $(95 \% \mathrm{Cl})$ and the number of included studies. Where there were no available meta-analyses, findings from systematic reviews were compared narratively. The overall score from the AMSTAR quality assessment and the $\mathrm{I}^{2}$ heterogeneity score were incorporated in the interpretation of the findings of each review. The forest plots were created in $R$ statistical software (40) AND A map showing the distribution of all the index studies included in the included reviews was created using Tableau software (41).

For the updated meta-analysis, the quality effects model (42) was employed to pool the estimates (odds ratios), as it is more robust and performs better than the random-effects model (43). In some studies where outcome assessed cases were zero, a post hoc continuity correction adding (0.5) to all cells was employed for valid estimation of the odds ratio and its variance. Forest plots were used to depict the results of the pooled analysis. The quality effects method uses a relative quality rank from each of the studies to modify the study's variance weight, thereby incorporating the quality of the study quantitatively into the results. The results of random effects analyses were reported in the supplementary material for comparison only if there was heterogeneity as without this it defaults to a fixed effect model similar to the quality effects model. The Stata software program (44) was utilized for meta-analysis. Forest plots were used to present the pooled odds ratios and their confidence intervals (Cls) (45). The Cochran $Q$ test $p$ value was used to test for and the $\mathrm{I}^{2}$ statistic to quantify heterogeneity (46). The $\mathrm{I}^{2}$ statistic measures consistency and is an indication of the variability in the estimates of the effects that are caused by heterogeneity instead of sampling error, and ranges from a $0 \%$ (no heterogeneity) to $100 \%$ (high heterogeneity). $\mathrm{I}^{2}$ values above $50 \%$ indicate substantial heterogeneity and above $75 \%$ high heterogeneity. Doi plots and the LFK 
medRxiv preprint doi: https://doi.org/10.1101/2020.07.28.20164012; this version posted July 9, 2021. The copyright holder for this preprint (which was not certified by peer review) is the author/funder, who has granted medRxiv a license to display the preprint in perpetuity.

It is made available under a CC-BY-NC-ND 4.0 International license.

index (47) were used for assessing publication bias as they are more easier to interpret than funnel plots and in this case funnel plots could not be used as they are not recommended when there are less than 10 studies in a meta-analysis (48).

\section{Ethics}

Ethics approval was not required as the study used published data. 
medRxiv preprint doi: https://doi.org/10.1101/2020.07.28.20164012; this version posted July 9, 2021. The copyright holder for this preprint (which was not certified by peer review) is the author/funder, who has granted medRxiv a license to display the preprint in perpetuity.

It is made available under a CC-BY-NC-ND 4.0 International license .

\section{Results}

\section{Fig.1: Flow chart for the meta-review}
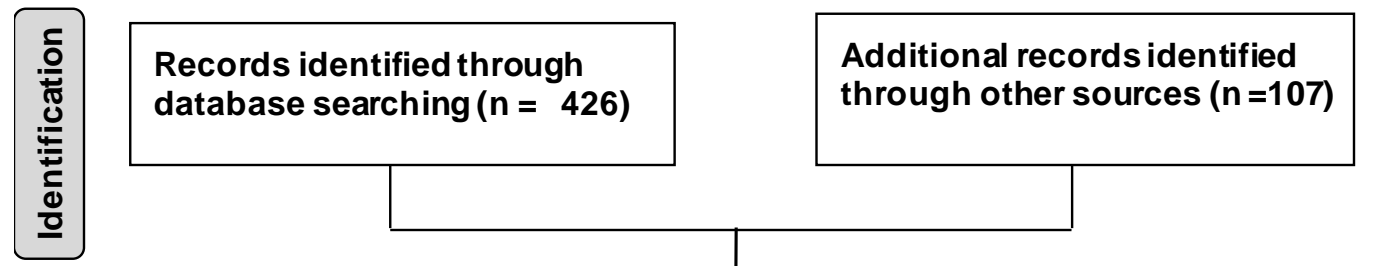

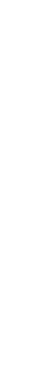

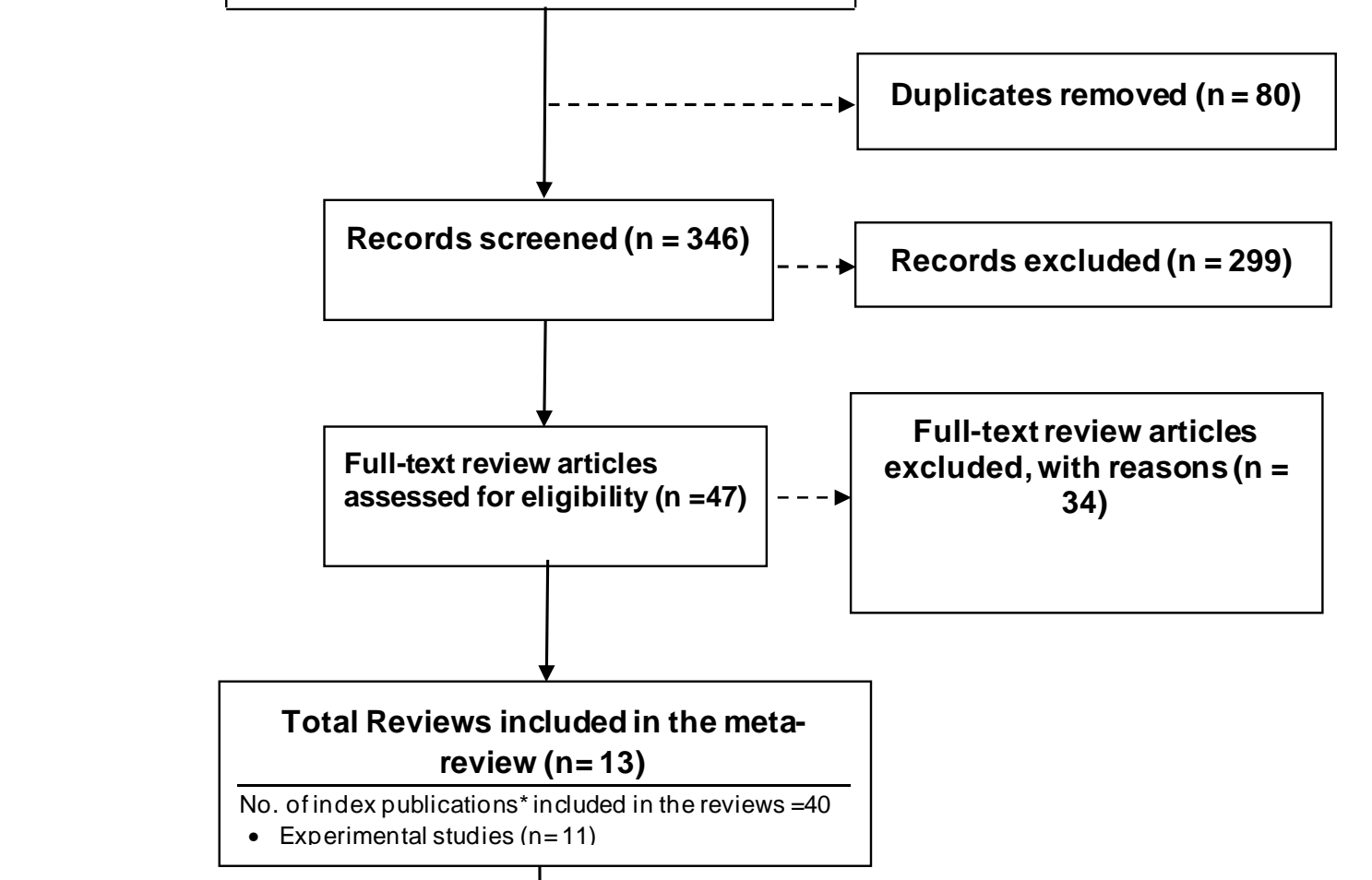

**Additional screening for eligible RCTs that are not included in the meta-review (Included, $n=3$, Excluded, COVID not PCR confirmed for most participants $^{* * * *}, \mathrm{n}=2$ )

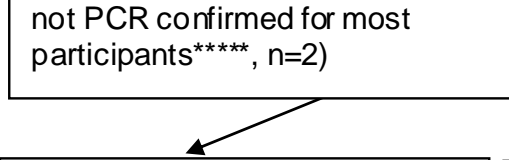

Articles with efficacy outcomes included in the meta-review

Reviews ( $n=12$ )

Additional primary studies $(n=3)$

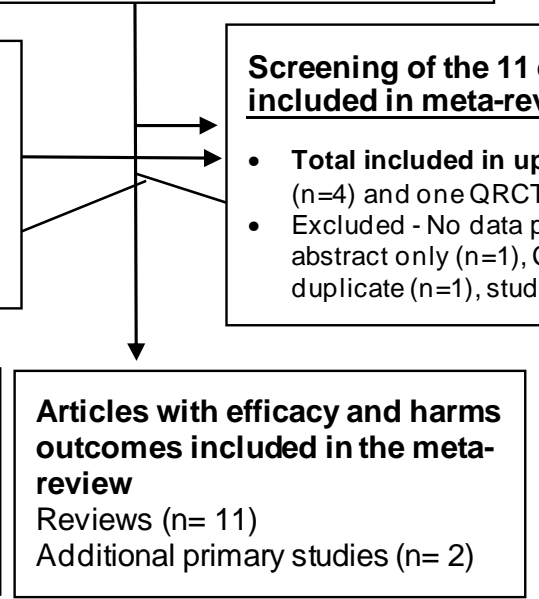

Screening of the 11 experimental studies that are

Total included in updated meta-analysis $=8(7 \mathrm{RCT}$ T)

presented $(n=1), C Q$ vs $C Q^{* *}(n=1)$, COVID19 not PCR confirmed $(n=1)$

Articles focused on harms
outcomes included in the
meta-review
Reviews $(n=1)$
Additional primary studies $(n=0)$

*Index publication is the firstoccurrence of a primary publication in the included reviews. ${ }^{* *}$ Additional eligible primary studies that had not been initially identified by the search of the relevant reviews or obtained by updating the search of the included reviews. ${ }^{* * *}$ study compared high dose chloroquine against a low dose chloroquine. ${ }^{* * *}$ study design not clear as both groups received $H C Q,{ }^{* * * *}$ most participants in study diagnosed using symptoms and not PCR 


\section{Search results and characteristics of included reviews}

The search identified 158 reviews and 111 were excluded by screening the title and abstract (Fig 1). Most reviews were excluded because they were either literature reviews or reviews which did not include completed clinical studies (Fig 1 and Supplementary Table S2). The remaining 47 reviews were screened for eligibility through reading the full text and 24 were provisionally included. One additional review was identified through manual searching of references and the citations search. The final included reviews were 13 , of which $5(38.5 \%)$ were systematic reviews and metaanalyses and the remainder systematic reviews only (Table 1).

The characteristics of the included reviews and experimental studies are summarised in Table 1 and Table 2 respectively. The quality assessment of the included reviews and experimental studies are shown in Supplementary Tables 3 and 4, respectively.

Table 1. Characteristics of included reviews

\begin{tabular}{|c|c|c|c|c|}
\hline $\begin{array}{l}\text { First author, date of } \\
\text { publication/submission, study } \\
\text { design }\end{array}$ & Scope of review & $\begin{array}{l}\text { Types of included studies } \\
\text { and total participants }\end{array}$ & $\begin{array}{l}\text { Tool used to assess risk } \\
\text { of bias }\end{array}$ & ROB summary \\
\hline $\begin{array}{l}\text { Sarma (13 April 2020) (49) } \\
\text { Design - SRMA }\end{array}$ & $\begin{array}{l}\text { Evaluation of safety and } \\
\text { efficacy of } \mathrm{HCQ} \text { alone or in } \\
\text { combination }\end{array}$ & $\begin{array}{l}\text { RCTs }-3 \\
\text { Observational - } 4 \\
\text { Participants }-1358\end{array}$ & $\begin{array}{l}\text { ROBINS-I tool, } \\
\text { Newcastle } \\
\text { Ottawa Scale }\end{array}$ & $\begin{array}{l}\text { High risk of selection, } \\
\text { performance and detection } \\
\text { bias. Unclear risk of bias in } \\
\text { attrition \& reporting bias }\end{array}$ \\
\hline $\begin{array}{l}\text { Chowdhury (28 April 2020) } \\
\text { (28) } \\
\text { Design - SR }\end{array}$ & $\begin{array}{l}\text { To review the literature } \\
\text { currently available regarding } \\
\text { the clinical use of CQ and } \mathrm{HCQ} \\
\text { as treatment in COVID-19 }\end{array}$ & $\begin{array}{l}\text { RCTs - } 7 \\
\text { Total participants }=486\end{array}$ & Cochrane ROB tool & $\begin{array}{l}\text { High risk (randomization, } \\
\text { allocation concealment, and } \\
\text { overall risk). } 3 \mathrm{RCTs}, 2 \text { single } \\
\text { arm, } 1 \text { observational }\end{array}$ \\
\hline $\begin{array}{l}\text { Singh (7 May 2020) (50) } \\
\text { Design - SRMA }\end{array}$ & $\begin{array}{l}\text { Efficacy of HCQ in COVID-19 } \\
\text { subjects on viral clearance and } \\
\text { death due to all causes. }\end{array}$ & $\begin{array}{l}\text { RCTs }=5(2 \text { non- } \\
\text { randomized CT } \\
\text { Observational }=5 \\
\text { Total participants }=2042\end{array}$ & $\begin{array}{l}\text { Jadad checklist, } \\
\text { ROBINS I tool, } \\
\text { Newcastle-Ottawa Scale }\end{array}$ & $\begin{array}{l}5 / 8 \text { on Jadad checklist, } \\
\text { Moderate quality on ROBINS I } \\
\text { tool }(n=2), 7 / 8 \text { on Newcastle- } \\
\text { Ottawa Scale }(n=2)\end{array}$ \\
\hline $\begin{array}{l}\text { Suranagi (13 May 2020) (51) } \\
\text { Design - SR }\end{array}$ & $\begin{array}{l}\text { To systematically explore, } \\
\text { analyse, rate the existing } \\
\text { evidence of } \\
\text { hydroxychloroquine in the light } \\
\text { of published, unpublished and } \\
\text { clinical trial data. }\end{array}$ & $\begin{array}{l}\text { RCTs- } 3 \\
\text { Observational - } 5 \\
\text { Total participants - } 2047\end{array}$ & $\begin{array}{l}\text { Oxford CEBM critical } \\
\text { appraisal tool }\end{array}$ & $\begin{array}{l}\text { Risk of bias was serious-very } \\
\text { serious. Level of evidence } \\
\text { quality/strength rating was } \\
\text { GRADE level (low-very low) } \\
\text { and CEBM level 2b-3b }\end{array}$ \\
\hline Yang (14 May 2020) (52) & $\begin{array}{l}\text { To demonstrate the } \\
\text { significance of present }\end{array}$ & RCTs- 3 & $\begin{array}{l}\text { The Modified Downs } \\
\text { and Black risk }\end{array}$ & $\begin{array}{l}\text { The average Downs and } \\
\text { Black score were } 19, \text { with a }\end{array}$ \\
\hline
\end{tabular}


medRxiv preprint doi: https://doi.org/10.1101/2020.07.28.20164012; this version posted July 9, 2021. The copyright holder for this preprint (which was not certified by peer review) is the author/funder, who has granted medRxiv a license to display the preprint in perpetuity.

It is made available under a CC-BY-NC-ND 4.0 International license .

\begin{tabular}{|c|c|c|c|c|}
\hline Design - SRMA & $\begin{array}{l}\text { evidence regarding benefits } \\
\text { and safety of HCQ for } \\
\text { treatment of COVID-19 }\end{array}$ & $\begin{array}{l}\text { Observational - } 2 \\
\text { Total participants - } 677\end{array}$ & assessment scale & range between 18 and 22 \\
\hline Design - SR & $\begin{array}{l}\text { To summarize evidence from } \\
\text { human clinical studies for using } \\
\text { HCQ or CQ as antiviral agents } \\
\text { for any viral infection } \\
20 \text { agents for any viral infection }\end{array}$ & $\begin{array}{l}\text { RCTs }-6 \\
\text { Total participants - } 387\end{array}$ & $\begin{array}{l}\text { Cochrane risk of bias } \\
\text { tool and Robbins }\end{array}$ & $\begin{array}{l}\text { Average score (3-5 out of } 7) \text {. } \\
\text { Main types of bias were } \\
\text { selection, reporting, } \\
\text { performance and detection } \\
\text { bias }\end{array}$ \\
\hline $\begin{array}{l}\text { Chacko (20 May 2020) (54) } \\
\text { Design - SRMA }\end{array}$ & $\begin{array}{l}\text { To evaluate the efficacy and } \\
\text { safety of hydroxychloroquine } \\
\text { among patients with COVID-19 } \\
\text { infection. }\end{array}$ & $\begin{array}{l}\text { RCTs }-3 \\
\text { Observational }-8 \\
\text { Total participants } 4306\end{array}$ & $\begin{array}{l}\text { Cochrane risk of bias } \\
\text { tool and Robbins- } 1\end{array}$ & $\begin{array}{l}\text { Observational (3 low risk, } 4 \\
\text { moderate, } 1 \text { high risk), RCT } \\
\text { (risk of randomisation bias, } \\
\text { allocation bias and blinding) }\end{array}$ \\
\hline $\begin{array}{l}\text { Hernandez (27 May 2020) } \\
(30) \\
\text { Design - SR }\end{array}$ & $\begin{array}{l}\text { Summarize evidence about the } \\
\text { benefits and harms of HCQ or } \\
\text { CQ treatment or prophylaxis of } \\
\text { (COVID-19). }\end{array}$ & $\begin{array}{l}\text { RCT }-3 \\
\text { Observational - } 20 \\
\text { Total participants - } 4186\end{array}$ & $\begin{array}{l}\text { ROBINS-I and the } \\
\text { Cochrane Risk of Bias } \\
2.0\end{array}$ & $\begin{array}{l}\text { Either no information or some } \\
\text { concerns of bias to critical risk } \\
\text { of bias }\end{array}$ \\
\hline $\begin{array}{l}\text { Shamshirian (28 May 2020) } \\
\text { (55) } \\
\text { Design - SRMA }\end{array}$ & $\begin{array}{l}\text { A review to overcome the } \\
\text { controversies about the } \\
\text { effectiveness of HCQ against } \\
\text { COVID-19 }\end{array}$ & $\begin{array}{l}\text { RCTs - } 14 \\
\text { Observational - } 7 \\
\text { Total participants - } 103486\end{array}$ & $\begin{array}{l}\text { Jadad scale, ROBINS-I } \\
\text { tool and Newcastle- } \\
\text { Ottawa Scale }\end{array}$ & $\begin{array}{l}\text { High risk of bias in } \\
\text { randomisation sequence } \\
\text { generation, allocation } \\
\text { concealment, blinding and } \\
\text { outcome assessment }\end{array}$ \\
\hline $\begin{array}{l}\text { Das (28 May 2020) (56) } \\
\text { Design - SR }\end{array}$ & $\begin{array}{l}\text { Systematically review the } \\
\text { therapeutic role of HCQ in } \\
\text { COVID-19 }\end{array}$ & $\begin{array}{l}\text { RCT }-4 \\
\text { Observational - } 8\end{array}$ & $\begin{array}{l}\text { NOS, Cochrane ROB } \\
\text { tool }\end{array}$ & $\begin{array}{l}\text { High risk of bias in most } \\
\text { included studies }\end{array}$ \\
\hline $\begin{array}{l}\text { Takla (30 May 2020) (31) } \\
\text { Design - SR }\end{array}$ & $\begin{array}{l}\text { Clarify the strength of evidence } \\
\text { for the relative efficacy and } \\
\text { safety of } C Q \text { and } \mathrm{HCQ} \\
\text { treatment }\end{array}$ & $\begin{array}{l}\text { RCTs- } 4 \\
\text { Observational - } 15 \\
\text { Total participants - } 107948\end{array}$ & $\begin{array}{l}\text { Checklist of Review } \\
\text { Criteria - Task Force of } \\
\text { Academic Medicine and } \\
\text { GERIME committee }\end{array}$ & $\begin{array}{l}\text { All the studies included scored } \\
13 \text { in the risk assessment } \\
\text { criteria. " } 12 \text { were judged to be } \\
\text { of scientific rigour" }\end{array}$ \\
\hline $\begin{array}{l}\text { Jankelson (31 May 2020) (23) } \\
\text { Design - SR }\end{array}$ & $\begin{array}{l}\text { Review risk of QT prolongation, } \\
\text { torsades, ventricular } \\
\text { arrhythmia and sudden death } \\
\text { with short courses of CQ and } \\
\text { HCQ in COVID-19 }\end{array}$ & $\begin{array}{l}\text { RCTs }-5 \\
\text { Observational }-6 \\
\text { Total participants - } 1515\end{array}$ & None reported & Not reported \\
\hline $\begin{array}{l}\text { Wang (1 June 2020) (57) } \\
\text { Design - SR }\end{array}$ & $\begin{array}{l}\text { Assess the published studies } \\
\text { of Chloroquine (CQ) and } \\
\text { hydroxychloroquine (HCQ) for } \\
\text { the treatment of COVID-19 }\end{array}$ & $\begin{array}{l}\text { RCTs - } 10 \\
\text { Total participants - } 1831\end{array}$ & Not reported & Not reported \\
\hline
\end{tabular}

All the included reviews were conducted between 13 April and the $1^{\text {st }}$ of June 2020 . At

the time that this meta-review was carried out, 10 of the included reviews were

published $(23,28,30,31,49,50,52-55)$ and the remaining three $(51,54,57)$ were 
medRxiv preprint doi: https://doi.org/10.1101/2020.07.28.20164012; this version posted July 9, 2021. The copyright holder for this preprint (which was not certified by peer review) is the author/funder, who has granted medRxiv a license to display the preprint in perpetuity. It is made available under a CC-BY-NC-ND 4.0 International license.

preprints. All the included reviews assessed the efficacy and the safety of the CQ and HCQ in the treatment of COVID-19, except Jankelson et al. 2020 (23) which only assessed adverse events associated with $\mathrm{CQ}$ and $\mathrm{HCQ}$.

Most of the included reviews had above 7 safeguards and only 2 reviews $(23,57)$ had 6 or lower safeguard counts on the AMSTAR scale (Supplementary Fig. 1 \& Supplementary Table S3). The same 2 reviews did not report that they assessed for risk of bias in their included index studies. One (57) of the two reviews which did not report assessing the risk of bias in included studies was not published at the time of this umbrella review. The reported quality of included index studies in the reviews was generally poor, with 7 reviews $(28,49,54,56)$ reporting a low count of safeguards in general. The most common issues were lack of safeguards against selection bias, lack of randomization, lack of allocation concealment bias, absence of blinding and performance and reporting biases. Most of the included reviews had the limitations of a small number of included index studies, lack of proper control groups or improper randomization among the included primary studies. An additional limitation of the reviews was the mixing of results from observational and experimental studies in the meta-analyses of efficacy. 
Fig 2. Location of all primary studies in included reviews

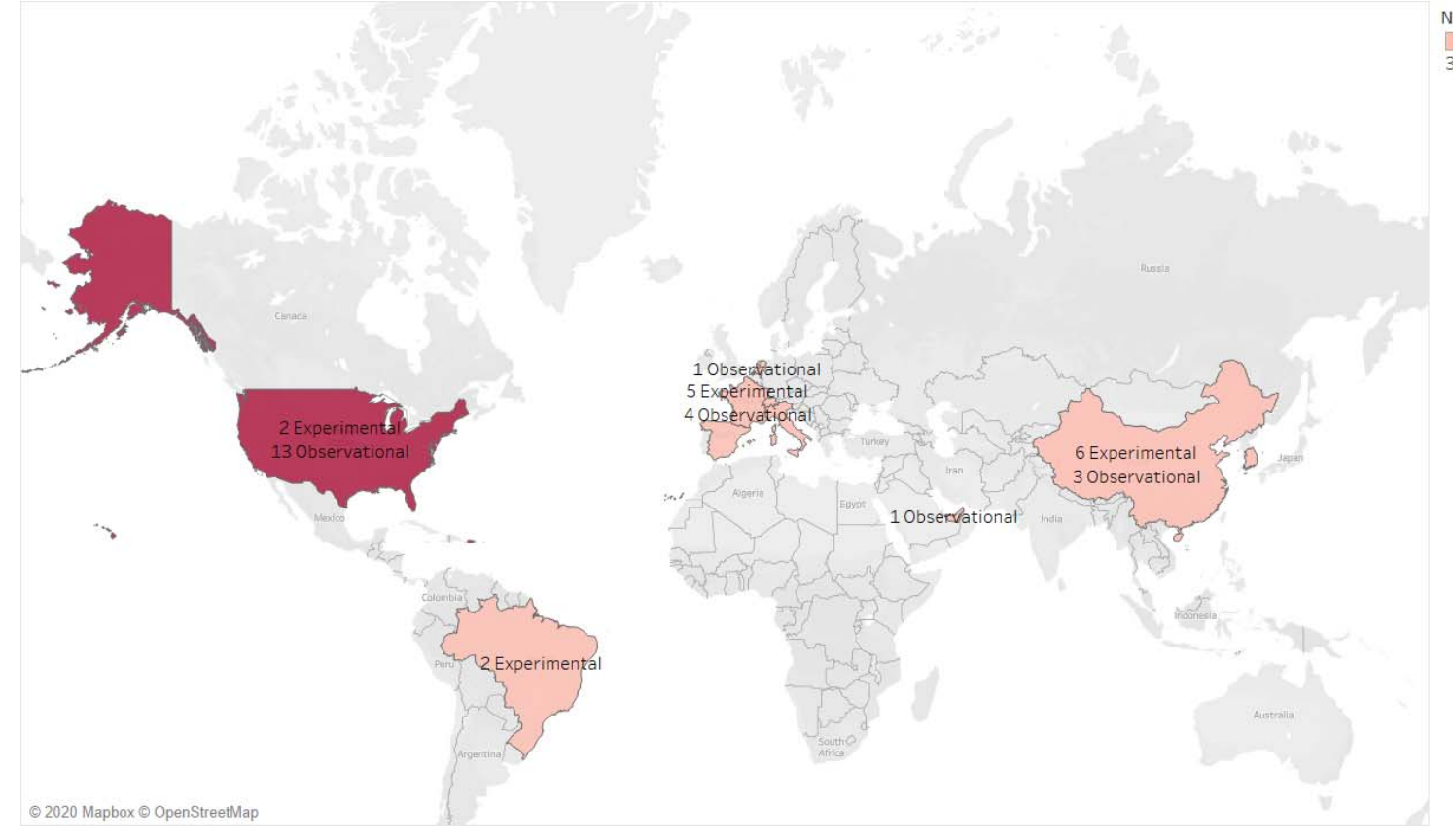

$N$ - sample size of the index study

\section{Characteristics of primary studies included in reviews and the updated meta-analysis}

The total number of index studies in the included reviews, after removing duplicate studies was 40 . Most of the included primary studies were conducted in the USA (14 studies, 108011 participants), followed by China (9 studies, 1975 participants) and France (9 studies, 1637 participants) (Fig 2). The total number of participants in all the reviews after removing duplicate studies was 113 786. All the included reviews included at least 3 experimental studies and the number of included observational studies ranged from zero in 3 reviews $(28,53,57)$ to 20 in one review $(55)$.

The observational index studies were excluded from the updated meta-analysis (Supplementary Table S4). After screening the 11 studies described as experimental studies in the included reviews, only 5 experimental studies $(20,58-60)$ satisfied the criteria for inclusion in the updated meta-analysis (Fig. 1). The reasons for exclusion of the other experimental studies were as follows; duplicate study $(n=1)(61)$ which used data from Gautret et al. 2020 (20), one study had no full text available (62), one study compared high dose chloroquine to low dose chloroquine (63), and one study included 
participants who did not have COVID-19 confirmed by PCR (64). Another experimental study was excluded because it was a letter to the editor describing 15 trials with a total of 100 patients but with no clear details about the trials, the participants or any outcomes (65). Finally one study (66) was described by the authors as quasi experimental as two institutions treated patients confirmed as positive with HCQ but study subjects in both institutions received HCQ. One institution received HCQ shortly after admission, and in the other institution did not receive HCQ until days later when PCR results came through so there was no real control arm and was not published with a submission version of the pdf circulated on the internet. Five trials were identified from the additional search, with three included $(24,67,68)$ and two $(69,70)$ excluded as they included participants who were diagnosed using symptoms rather than PCR (Fig. 1).

Table 2. Characteristics of experimental studies included in the updated metaanalysis 
medRxiv preprint doi: https://doi.org/10.1101/2020.07.28.20164012; this version posted July 9, 2021. The copyright holder for this preprint (which was not certified by peer review) is the author/funder, who has granted medRxiv a license to display the preprint in perpetuity.

\begin{tabular}{|c|c|c|c|c|c|c|c|}
\hline $\begin{array}{l}\text { Study and } \\
\text { date of } \\
\text { publication }\end{array}$ & $\begin{array}{l}\text { Design and } \\
\text { setting }\end{array}$ & $\begin{array}{l}\text { Itsámade avc } \\
\text { size and } \\
\text { age } \\
\text { (mean, } \\
\text { years) }\end{array}$ & $\begin{array}{l}\text { lablengnger a } \\
\text { dose }\end{array}$ & Ce-Butrole-ND 4.0 Int & $\begin{array}{l}\text { ratúght licens } \\
\text { comorbiditie } \\
\mathrm{s}\end{array}$ & $\begin{array}{l}\% \text { of } \\
\text { infection } \\
\text { severity }\end{array}$ & $\begin{array}{l}\text { Outcomes } \\
\text { and length of } \\
\text { follow-up }\end{array}$ \\
\hline $\begin{array}{l}\text { Huang et al., } \\
\text { 18-May- } \\
2020(58)\end{array}$ & $\begin{array}{l}\text { RCT, } \\
\text { hospital } \\
\text { Country - } \\
\text { China }\end{array}$ & $\begin{array}{l}22 \\
\text { participant } \\
\text { s } \\
\text { Mean age } \\
44.0 \text { yrs } \\
\text { (Range } \\
36.5-57.5 \text { ) }\end{array}$ & $\begin{array}{l}10 \\
\text { participant } \\
\text { s received } \\
\text { CQ (500 } \\
\text { mg orally } \\
\text { twice daily } \\
\text { for } 10 \\
\text { days) }\end{array}$ & $\begin{array}{l}12 \text { participants } \\
\text { received } \\
\text { Lopinavir/Ritonavi } \\
\text { r ( } 400 / 100 \mathrm{mg} \\
\text { orally twice daily } \\
\text { for } 10 \text { days) }\end{array}$ & Not reported & $36.4 \%$ & $\begin{array}{l}\text {-Negative } \\
\text { conversion } \\
\text { of SARS- } \\
\text { CoV-2 } \\
\text { - lung CT for } \\
\text { assessing the } \\
\text { improvement } \\
\text { of NCP } \\
\text {-length of } \\
\text { hospitalizatio } \\
\text { n } \\
\text {-Adverse } \\
\text { events }\end{array}$ \\
\hline $\begin{array}{l}\text { Tang et al., } \\
\text { 7-May-2020 } \\
\text { (59) }\end{array}$ & $\begin{array}{l}\text { Open-label } \\
\text { RCT, } \\
16 \\
\text { government- } \\
\text { designed } \\
\text { COVID-19 } \\
\text { treatment } \\
\text { centers } \\
\text { Country - } \\
\text { China }\end{array}$ & $\begin{array}{l}150 \\
\text { participant } \\
\text { s } \\
\text { Mean age } \\
48.0 \text { yrs } \\
\text { (SD 14.1) }\end{array}$ & $\begin{array}{l}75 \\
\text { participant } \\
\text { s received } \\
\text { HCQ } \\
(1200 \mathrm{mg} \\
\text { for } 3 \text { days } \\
\text { then } \\
\text { maintained } \\
800 \mathrm{mg} \text { for } \\
\text { rest of the } \\
\text { follow up) } \\
+ \text { SOC }\end{array}$ & $\begin{array}{l}75 \text { participants } \\
\text { received SOC only }\end{array}$ & $\begin{array}{l}16 \% \text { DM } \\
\text { and } 8 \% \\
\text { HTN }\end{array}$ & $\begin{array}{l}\text { All } \\
\text { participants } \\
\text { had mild- } \\
\text { moderate } \\
\text { disease, } \\
\text { except } 2 \text { were } \\
\text { severe }\end{array}$ & $\begin{array}{l}\text {-Negative } \\
\text { conversion } \\
\text { of SARS- } \\
\text { CoV-2 by } 28 \\
\text { days } \\
\text {-Adverse } \\
\text { events }\end{array}$ \\
\hline $\begin{array}{l}\text { Chen Z et } \\
\text { al., } \\
10-\text { April- } \\
2020(60)\end{array}$ & $\begin{array}{l}\text { RCT } \\
\text { (double- } \\
\text { blind), } \\
\text { Renmin } \\
\text { Hospital of } \\
\text { Wuhan } \\
\text { University } \\
\text { Country - } \\
\text { China }\end{array}$ & $\begin{array}{l}62 \\
\text { participant } \\
\text { s } \\
\text { Mean age } \\
44.7(15.3)\end{array}$ & $\begin{array}{l}31 \\
\text { received } \\
\text { HCQ }(400 \\
\mathrm{mg} / \mathrm{d}(200 \\
\mathrm{mg} / \mathrm{bid}) \\
\text { between } \\
\text { days } 1 \text { and } \\
5)+ \text { SOC }\end{array}$ & $\begin{array}{l}\text { 31participants } \\
\text { received SOC only }\end{array}$ & Not reported & $\begin{array}{l}4(6.5 \%) \text { had } \\
\text { severe } \\
\text { infection in } \\
\text { control group }\end{array}$ & $\begin{array}{l}\text {-Changes in } \\
\text { TTCR } \\
\text {-Adverse } \\
\text { events } \\
\text {-Mortality }\end{array}$ \\
\hline $\begin{array}{l}\text { Gautret et } \\
\text { al., } \\
\text { 20-March- } \\
2020(20)\end{array}$ & $\begin{array}{l}\text { Open-label, } \\
\text { quasi- } \\
\text { experimental } \\
, 4 \text { centres } \\
\text { Country - } \\
\text { France }\end{array}$ & $\begin{array}{l}2 \\
\text { participant } \\
\mathrm{s} \\
\text { Mean age } \\
45.1(22.0)\end{array}$ & $\begin{array}{l}26 \\
\text { participant } \\
\text { s received } \\
\text { HCQ } \\
\text { (200mg, } 3 \\
\text { times daily } \\
\text { for } 10 \\
\text { days) } \\
6 \\
\text { participant } \\
\text { s received } \\
\text { AZI } \\
\text { (500mg } \\
\text { day } 1, \\
\text { followed } \\
\text { by } 250 \mathrm{mg} \\
\text { daily for } \\
\text { the next } 4 \\
\text { days }\end{array}$ & $\begin{array}{l}16 \text { participants } \\
\text { refused the } \\
\text { protocol treatment }\end{array}$ & Not reported & $\begin{array}{l}16.7 \% \text { were } \\
\text { asymptomatic } \\
, 61.1 \% \text { with } \\
\text { URTI and } \\
22.2 \% \text { with } \\
\text { LRTI }\end{array}$ & $\begin{array}{l}\text {-Viral } \\
\text { clearance at } \\
\text { day } 6 \\
\text {-Mortality } \\
\text {-Adverse } \\
\text { events }\end{array}$ \\
\hline $\begin{array}{l}\text { Chen J et } \\
\text { al., } \\
\text { 6-March- } \\
2020(22)\end{array}$ & $\begin{array}{l}\text { Open-label } \\
\text { RCT, } \\
\text { Shanghai } \\
\text { Public } \\
\text { Health } \\
\text { Clinical } \\
\text { Center }\end{array}$ & $\begin{array}{l}30 \\
\text { participant } \\
\text { s } \\
\text { Mean age } \\
48.6 \text { yrs } \\
\text { (no SD } \\
\text { reported) }\end{array}$ & $\begin{array}{l}15 \\
\text { participant } \\
\text { s received } \\
\text { oral HCQ } \\
\text { (400mg } \\
\text { once daily } \\
\text { for } 5 \text { days }) \\
+ \text { SOC }\end{array}$ & $\begin{array}{l}15 \text { participants } \\
\text { received SOC only }\end{array}$ & $\begin{array}{l}36.7 \% \text { with } \\
\text { comorbid } \\
\text { disease }\end{array}$ & Not reported & $\begin{array}{l}\text { - Negative } \\
\text { conversion } \\
\text { of SARS- } \\
\text { CoV-2 at day } \\
7 \\
\text {-Disease } \\
\text { exacerbation } \\
\text { and adverse }\end{array}$ \\
\hline
\end{tabular}


medRxiv preprint doi: https://doi.org/10.1101/2020.07.28.20164012; this version posted July 9, 2021. The copyright holder for this preprint (which was not certified by peer review) is the author/funder, who has granted medRxiv a license to display the preprint in perpetuity.

\begin{tabular}{|c|c|c|c|c|c|c|c|}
\hline & $\begin{array}{l}\text { Country - } \\
\text { China }\end{array}$ & & & & & & events \\
\hline $\begin{array}{l}\text { Horby et al. } \\
\text { RECOVER } \\
\text { Y TRIAL } \\
\text { 15- July } \\
2020(24)\end{array}$ & $\begin{array}{l}\text { Adaptive } \\
\text { RCT } \\
\text { Country - } \\
\text { U.K. }\end{array}$ & $\begin{array}{l}4647 \\
\text { participant } \\
\text { s } \\
\text { Mean age } \\
65.3 \text { yrs } \\
\text { (SD 15.3) }\end{array}$ & $\begin{array}{l}1542 \\
\text { participant } \\
\text { s received } \\
\text { a loading } \\
\text { dose of } \\
\text { HCQ of } \\
800 \mathrm{mg} \\
\text { twice on } \\
\text { the first } \\
\text { day, then } \\
400 \mathrm{mg} \\
\text { twice a } \\
\text { day for } 6 \\
\text { days }\end{array}$ & $\begin{array}{l}3132 \text { participants } \\
\text { on SOC }\end{array}$ & $\begin{array}{l}57 \% \text { had at } \\
\text { least one } \\
\text { major } \\
\text { comorbidity }\end{array}$ & $\begin{array}{l}76 \% \text { were } \\
\text { either on } \\
\text { mechanical } \\
\text { ventilation or } \\
\text { supplementar } \\
\text { y oxygen }\end{array}$ & $\begin{array}{l}\text { Mortality } \\
\text { after } 28 \text { days }\end{array}$ \\
\hline $\begin{array}{l}\text { Chen C.P. et } \\
\text { al. } 10 \text { July } \\
2020 \text { (67) }\end{array}$ & $\begin{array}{l}\text { RCT } \\
\text { Country - } \\
\text { Taiwan }\end{array}$ & $\begin{array}{l}33 \\
\text { participant } \\
\text { s } \\
\text { Mean age } \\
32.9 \text { yrs } \\
\text { (SD 10.7) }\end{array}$ & $\begin{array}{l}21 \\
\text { participant } \\
\text { s received } \\
400 \mathrm{mg} \\
\text { HCQ } \\
\text { twice a } \\
\text { day on day } \\
\text { one, then } \\
200 \mathrm{mg} \\
\text { twice a } \\
\text { day for } 6 \\
\text { days }\end{array}$ & $\begin{array}{l}12 \text { participants on } \\
\text { SOC }\end{array}$ & $\begin{array}{l}\text { A "few" had } \\
\text { comorbiditie } \\
\text { S }\end{array}$ & $\begin{array}{l}\text { Mild to } \\
\text { moderate } \\
\text { illness. } \\
\text { Severe illness } \\
\text { excluded. }\end{array}$ & $\begin{array}{l}\text { Negative } \\
\text { rRT-PCR at } \\
14 \text { days }\end{array}$ \\
\hline $\begin{array}{l}\text { Mitjà et al. } \\
10 \text { July } 2020 \\
\text { (68) }\end{array}$ & $\begin{array}{l}\text { RCT } \\
\text { Country - } \\
\text { Spain }\end{array}$ & $\begin{array}{l}293 \\
\text { participant } \\
\text { s } \\
\text { Mean age } \\
41.6 \text { yrs } \\
\text { (SD 12.6) }\end{array}$ & $\begin{array}{l}136 \\
\text { participant } \\
\text { s received } \\
800 \mathrm{mg} \text { on } \\
\text { day } 1 \text {, then } \\
400 \mathrm{mg} \\
\text { once a day } \\
\text { for } 6 \text { days }\end{array}$ & $\begin{array}{l}157 \text { participants on } \\
\text { SOC }\end{array}$ & $53.2 \%$ & $\begin{array}{l}\text { All had mild } \\
\text { illness }\end{array}$ & $\begin{array}{l}\text {-Reduction of } \\
\text { viral load at } 7 \\
\text { days } \\
\text {-Disease } \\
\text { progression } \\
\text { by day } 28 \\
\text {-adverse } \\
\text { events by day } \\
28\end{array}$ \\
\hline
\end{tabular}

Abbreviations: $n-R C T$ - nonrandomized clinical trial, q-RCT- quasi-randomized control trial, HCQ- hydroxychloroquine, SOC - Standard of care, DM- Diabetes mellitus, HTN, hypertension, CVD-cardiovascular diseases, CHF- chronic heart failure, CKF-chronic kidney failure, TTCR- time to clinical recovery, URTI-upper respiratory tract infection, LRTI-lower respiratory tract infection

The eight experimental studies included in the updated meta-analysis (7 RCTs $(22,24,58-60,67,68)$ and 1 quasi-experimental study $(20))$, had a total of 5279 participants and 1856 on either $\mathrm{CQ} / \mathrm{HCQ}$ or $\mathrm{HCQ}$ with Azithromycin. Most of the studies $(n=4)$ were from China $(22,58,60,67)$ and the remaining 4 studies each from France $(n=1)(20)$, the U.K. (24), Spain (68) and Taiwan (59). Only one study used CQ (58) as the experimental drug while the remaining seven used HCQ. All seven (22, 24, $58-60,67,68$ ) included RCTs had safeguard counts (quality assessment) of at least 29 
medRxiv preprint doi: https://doi.org/10.1101/2020.07.28.20164012; this version posted July 9, 2021. The copyright holder for this preprint (which was not certified by peer review) is the author/funder, who has granted medRxiv a license to display the preprint in perpetuity. It is made available under a CC-BY-NC-ND 4.0 International license .

out of 36. The quasi-experimental study (20) had the lowest safeguard counts of 16. All the included studies, except Chen Z et al. 2020 (60), either did not blind or did not report sufficient information about blinding of either participants and research performers.

Other notable deficiencies included insufficient reporting of randomisation procedure and insufficient statistical analyses (Supplementary Fig.1B \& Supplementary Table S5).

\section{All-cause mortality}

\section{Findings from included reviews}

A total of 4 meta-analyses, all with AMSTAR quality safeguard counts of at least 10, reported pooled effect sizes for mortality (49, 50, 54, 55) (Fig. 3). For HCQ alone, two meta-analyses; Yang et al. 2020 (52) (677 participants, 5 studies) and Singh et al. 2020 (50)(2042 participants, 10 studies) found a higher risk of mortality with HCQ with odds ratios of 3.0 and 2.2, respectively, with no heterogeneity $\left(\mathrm{I}^{2}=0 \%\right.$ for both). The other 2 reviews, Shamshirian et al. 2020 (55) (103 486 participants, 21 studies) and Charko et al. 2020 (54) (4306 participants, 11 studies) found slight but non-significant increases in the risk of mortality with HCQ use, with significant heterogeneity in both meta-analyses. Only 2 reviews $(52,55)$ reported pooled analyses on HCQ with Azithromycin and both found a higher risk of mortality associated with the use of HCQ with Azithromycin, with similar odds ratios of 2.5 , with little heterogeneity in one and more heterogeneity in the other (Fig. 3). 
Fig 3. Results of meta-analyses - HCQ and all-cause mortality $H C Q$ $H C Q+A Z I$

\begin{tabular}{|c|c|c|c|c|c|c|c|}
\hline study & & Sample size & No. of studies & RR/OR & $95 \% \mathrm{Cl}$ & P-value & $1^{2}$ \\
\hline \multirow{2}{*}{ Shamshirian } & \multirow{2}{*}{$\longmapsto$} & \multirow{2}{*}{103486} & \multirow{2}{*}{21} & 1.13 & {$[0.7-1.8]$} & 0.594 & $91 \%$ \\
\hline & & & & 2.46 & {$[1.4-4.3]$} & 0.002 & $91 \%$ \\
\hline Chacko & - & 4306 & 11 & 1.41 & {$[0.8-2.6]$} & 0.28 & $84 \%$ \\
\hline Singh & $\square$ & 2042 & 10 & 2.17 & {$[1.3-3.6]$} & 0.002 & $00 \%$ \\
\hline \multirow{2}{*}{ Yang } & \multirow{2}{*}{$\bullet$} & \multirow{2}{*}{677} & \multirow{2}{*}{5} & 2.98 & {$[1.6-5.7]$} & 0.001 & $00 \%$ \\
\hline & & & & 2.54 & [1.4-4.5] & 0.001 & $00 \%$ \\
\hline
\end{tabular}

Of the reviews without meta-analysis, three concluded that there was evidence for higher risk of mortality in the HCQ group $(30,31,51,52)$ and one review (57) reported evidence of lower mortality in the HCQ group. Two reviews reported evidence of higher mortality in the chloroquine alone group $(30,53)$ (Supplementary Table S6).

\section{Updated meta-analysis of experimental studies}


medRxiv preprint doi: https://doi.org/10.1101/2020.07.28.20164012; this version posted July 9, 2021. The copyright holder for this preprint (which was not certified by peer review) is the author/funder, who has granted medRxiv a license to display the preprint in perpetuity.

Fig. 4. Updated meta-analysis of experimental studies - all-cause mortality

$\begin{array}{lll} & \text { Odds Ratio } & \% \\ \text { Study ID } & (95 \% \mathrm{Cl}) & \text { Weight }\end{array}$

Tang et al. 2020

Gautret et al. 2020

Chen J et al. 2020

Horby et al. 2020

Mitjà et al. 2020

Chen C. P. et al. 2020

Overall, QE $\left(I^{2}=0.0 \%, p=0.999\right)$

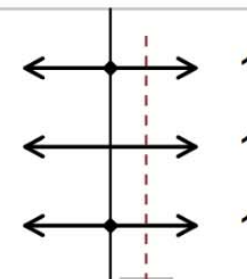

$1.00(0.02,51.05)$

0.14

$1.94(0.07,50.56)$

0.10

$1.00(0.02,53.66)$

0.13

$1.10(0.96,1.26)$

99.36

$.15(0.02,58.54)$

0.14

$0.58(0.01,31.16)$

0.13

$1.10(0.96,1.26)$

100.00

NOTE: Weights are from Doi's Quality Effects model

Six experimental studies, five RCTs $(22,24,59,67,68)$ and one quasi-experimental studies (20), assessed mortality, with a total of 5195 participants, of which 1815 were in the intervention group. There was no difference in the odds of mortality between participants who received HCQ with or without Azithromycin and those on standard care (OR 1.10, 95\% Cl $0.96-1.26$; Fig 4$)$, with consistency across studies $\left(I^{2}=0 \%\right)$. The Doi plot (Supplementary Fig. 3A) showed minor asymmetry, indicative of possible publication bias. As Horby et al. 2020 (24) had the most weight in the meta-analysis, we carried out a sensitivity analysis without this study and the pooled odds ratio for the effect of HCQ with or without Axithromycin on all-cause mortality remained unchanged (OR $1.02,95 \% \mathrm{Cl} 0.18-5.86, \mathrm{I}^{2}=0.0 \%$ ).

\section{Transfer to the ICU, intubation and mechanical ventilation}

\section{Findings from included reviews}

A total of seven reviews investigated the risk of transfer to ICU, need for intubation and mechanical ventilation. Only one meta-analysis (55) of two studies with a total of 308 participants was done and found a non-significant 2-fold increase in the odds of 
medRxiv preprint doi: https://doi.org/10.1101/2020.07.28.20164012; this version posted July 9, 2021. The copyright holder for this preprint (which was not certified by peer review) is the author/funder, who has granted medRxiv a license to display the preprint in perpetuity.

It is made available under a CC-BY-NC-ND 4.0 International license .

intubation in individuals on $\mathrm{HCQ}$ (OR 2.11, 95\%Cl 0.31-14.03), with high heterogeneity between their included studies. The remaining six reviews $(30,31,50,51,56,57)$ which did narrative syntheses reported no effect of $\mathrm{HCQ}$ in the risk of transfer to the ICU, intubation or need for mechanical ventilation (Supplementary Table S6).

\section{Updated meta-analysis of experimental studies}

Two RCTs $(24,68)$, and the quasi experimental study $(20)$, reported data on this outcome with a total of 4982 participants, of whom 1704 were in the intervention group. There was no significant difference in risk of ICU transfer, need for mechanical ventilation or intubation in participants who received HCQ with or without Azithromycin, compared to those on standard care (OR 1.11, 95\%Cl $0.88-1.41,12=0.0 \%$ ) (Fig. 5A). The Doi plot showed major asymmetry indicating possible publication bias (Supplementary Fig. 3B).

\section{Fig. 5. Updated meta-analysis of experimental studies - secondary outcomes}

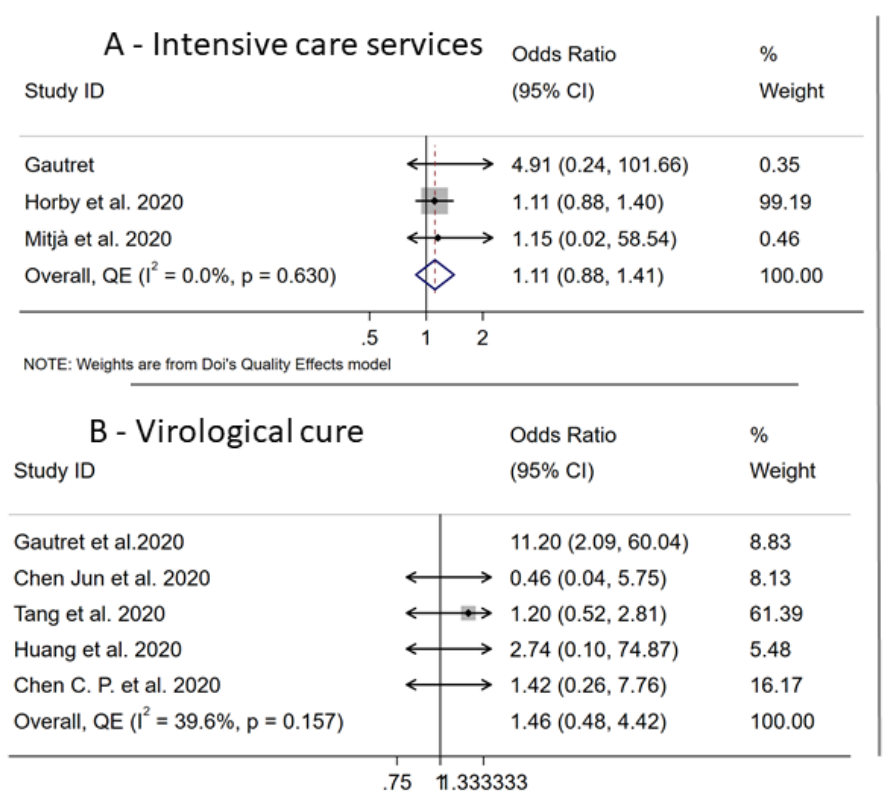

C - Disease exacerbation

\begin{tabular}{llll} 
Study ID & & Odds Ratio $(95 \% \mathrm{Cl})$ & Weight \\
\hline Chen J 2020 & & $3.21(0.12,85.20)$ & 7.98 \\
Chen Z 2020 & & $10.31(0.53,200.18)$ & 10.63 \\
Mitjà et al. 2020 & & $0.83(0.32,2.13)$ & 81.40 \\
Overall, $\mathrm{QE}\left(\mathrm{I}^{2}=31.9 \%, \mathrm{p}=0.230\right)$ & $1.21(0.25,5.87)$ & 100.00 \\
\hline & $125 \quad 8$ & \\
\hline
\end{tabular}

D - Adverse events

\begin{tabular}{|c|c|c|c|}
\hline \multirow{2}{*}{ Study ID } & \multirow{2}{*}{\multicolumn{2}{|c|}{ Odds Ratio $(95 \% \mathrm{Cl})$}} & \multirow{2}{*}{$\begin{array}{l}\% \\
\text { Weight }\end{array}$} \\
\hline & & & \\
\hline Chen J 2020 & s. & $1.45(0.26,8.01)$ & 8.13 \\
\hline Chen Z 2020 & & $5.34(0.25,115.89)$ & 3.82 \\
\hline Tang w 2020 & $\rightarrow$ & $4.47(1.77,11.31)$ & 26.17 \\
\hline Huang 2020 & & $25.00(1.17,535.24)$ & 3.37 \\
\hline Mitjà et al. 2020 & & $26.47(14.35,48.82)$ & 58.51 \\
\hline Overall, $\mathrm{QE}\left(\mathrm{I}^{2}=76.6 \%, \mathrm{p}=0.002\right)$ & $<$ & $12.33(2.54,59.92)$ & 100.00 \\
\hline
\end{tabular}

\section{Virological cure}

\section{Findings from included reviews}

Twelve reviews assessed the outcome of virological cure with 5 of the reviews being meta-analyses. All the 5 meta-analyses $(49,50,52,54,55)$ found no differences 
between either $\mathrm{HCQ}$ alone or $\mathrm{HCQ}$ with Azithromycin and control, in virological cure (Fig. 6A).

\section{Fig. 6. Results of meta-analyses on $\mathrm{HCQ}$ and virological cure and disease} exacerbation

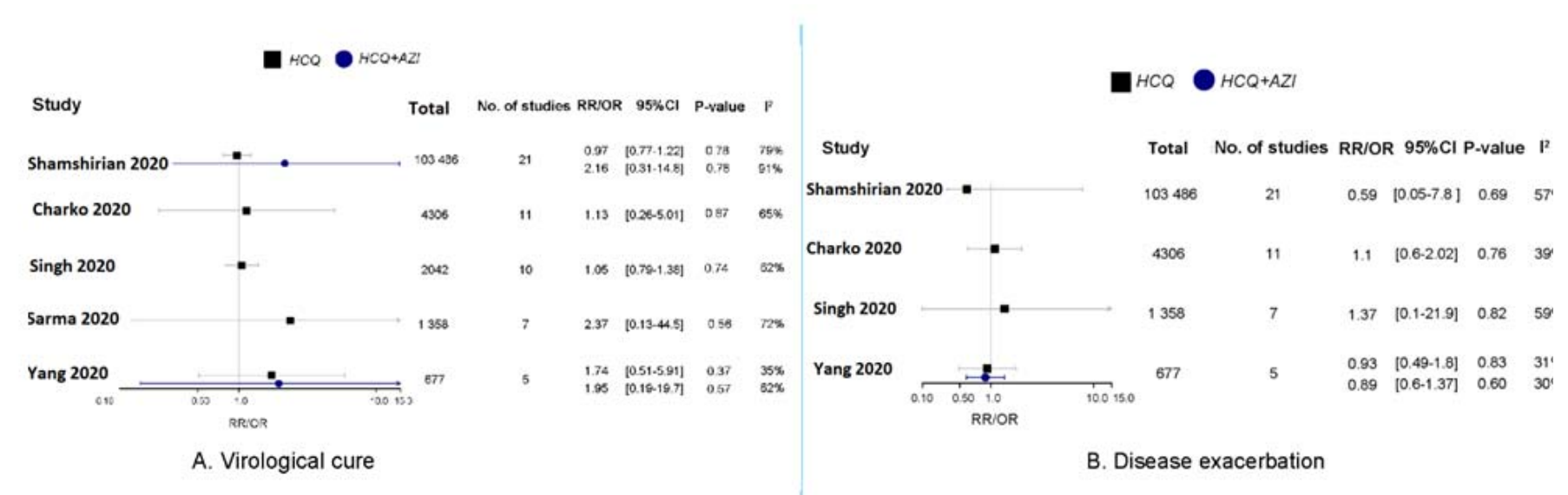

However, the remaining seven reviews $(28,30,31,51,53,56,57)$ which did narrative syntheses concluded that either HCQ alone or HCQ with Azithromycin were effective to some extent in the cure of the virus (Supplementary Table S6).

\section{Updated meta-analysis of experimental studies}

Five experimental studies, 4 RCTs $(20,22,58,59)$ and the single quasi-experimental study (20), assessed virological cure, with a total of 277 participants, of which 147 were in the intervention group. In pooled analyses, HCQ with or without Azithromycin appeared to improve virological cure although there was little evidence against the model hypothesis at this sample size (OR 1.46, 95\% Cl $0.48-4.48, \mathrm{I}^{2}=39.6 \%$ ) (Fig 5B). The Doi plot showed major asymmetry indicative of publication bias (Supplementary Fig. 3C). Removal of the quasi-experimental study, Gautret et al. 2020, did not alter the results of the pooled analysis (RR $1.0295 \% \mathrm{Cl} 0.91-1.14, \mathrm{I}^{2}=0 \%$ ). 
medRxiv preprint doi: https://doi.org/10.1101/2020.07.28.20164012; this version posted July 9, 2021. The copyright holder for this preprint (which was not certified by peer review) is the author/funder, who has granted medRxiv a license to display the preprint in perpetuity. It is made available under a CC-BY-NC-ND 4.0 International license .

\section{Disease exacerbation}

\section{Findings from reviews}

Four meta-analyses $(50,52,54,55)$, all with AMSTAR scores above 9, found that $\mathrm{HCQ}$ with or without Azithromycin had no effect on disease exacerbation (Fig 6B). The remaining reviews without meta-analysis on this outcome concluded that either HCQ or HCQ with Azithromycin reduced the severity of illness (Supplementary Table S6). Three reviews $(50,51,57)$ concluded that pneumonia was improved in the HCQ with or without Azithromycin arm.

\section{Updated meta-analysis of experimental studies}

Three RCTs $(22,60,68)$ assessed disease exacerbation, with a total of 385

participants, of which 182 were in the intervention group. The pooled analyses showed that $\mathrm{HCQ}$ with or without Azithromycin had no effect on disease exacerbation (OR 1.21, $95 \% \mathrm{Cl} 0.25-5.87, \mathrm{I}^{2}=31.9 \%$ ) (Fig. $5 \mathrm{C}$ ). The Doi plot showed major asymmetry.

\section{Adverse events}

\section{Findings from reviews}

A total of ten reviews investigated the risk of adverse events between HCQ or HCQ with Azithromycin groups and control. Two of these carried out meta-analyses and found pooled Odds Ratios of $3.9\left(95 \% \mathrm{Cl} 1.8-8.1, \mathrm{n}=4\right.$ studies, 304 participants, $\mathrm{I}^{2}=7.7 \%$ ) (55) and $4.1\left(95 \% \mathrm{Cl} 1.4-11.9, \mathrm{n}=4\right.$ studies, 1714 participants, $\left.\mathrm{I}^{2}=81 \%\right)(54)$. All the remaining 8 reviews $(23,28,31,49,51,56,57)$ except one $(30)$, found an increased risk of adverse events in the HCQ with or without Azithromycin group. The most reported adverse events were QTc interval prolongation diarrhea, arrythmia and firstdegree AV block (Supplementary Table S6).

\section{Updated meta-analysis of experimental studies}

Five RCTs $(22,58-60,68)$ assessed adverse events, with a total of 557 participants, of which 262 were in the intervention group. The most commonly reported adverse events due to $\mathrm{HCQ}$ and $C Q$ were gastrointestinal (nausea, vomiting, diarrhea and abdominal pain), reported in all five trials $(22,58-60,68)$, headache $(60,67,68)$ and itchiness and rash $(58,60)$. Serious adverse events were very rare and reported in only three participants in three of the included trials $(22,24,59)$. These included a single case of 
medRxiv preprint doi: https://doi.org/10.1101/2020.07.28.20164012; this version posted July 9, 2021. The copyright holder for this preprint (which was not certified by peer review) is the author/funder, who has granted medRxiv a license to display the preprint in perpetuity. It is made available under a CC-BY-NC-ND 4.0 International license .

torsades de pointes reported in the RECOVERY trial (24), two cases, one with blurred vision and the other with thirst, reported by Tang et al. 2020 (59) and a case described as "severe" but with no clear details, Chen J et al. 2020 (22). The pooled odds ratio showed a 12-fold increase in the odds of adverse events in participants who received HCQ with or without Azithromycin, compared to those on standard care (OR 12.33, 95\%Cl $2.54-59.92$, 12 = 76.6\%) (Fig. 5D). The Doi plot showed major asymmetry indicative of possible publication bias (Supplementary Fig. 3E).

\section{Conclusions from reviews}

Nine of the reviews $(28,30,50,51,53-57)$ all concluded that there was insufficient evidence to support the use of either $\mathrm{CQ}$ or $\mathrm{HCQ}$ with or without Azithromycin in the treatment of people with COVID-19. Two reviews concluded that there was some benefit in using HCQ with or without Azithromycin. Yang et al. 2020 (52) concluded that, although they were associated with higher mortality, HCQ with or without Azithromycin were beneficial, based on their effect on COVID-19 viral clearance. Sarma et al. 2020 (49) concluded that HCQ was beneficial based on its efficacy in reducing radiological progression and that the drug was safe. The remaining 2 reviews concluded that either $\mathrm{CQ}$ or $\mathrm{HCQ}$ were unsafe based on higher risk of mortality (31) and adverse events $(23,31)$.

\section{Discussion}

In this meta-review, we summarized the findings of seven systematic reviews and five meta-analyses and carried out an updated meta-analysis to investigate the efficacy and safety of $\mathrm{CQ}$ and $\mathrm{HCQ}$, with or without a second-generation macrolide antibiotic, Azithromycin, in individuals infected with COVID-19, limiting our analysis to eight experimental studies which met a strict inclusion criterion. Findings from the included reviews suggested that $\mathrm{HCQ}$ or $\mathrm{CQ}$ with or without Azithromycin had no benefit; two studies suggesting a 2-to-3-fold increase in the risk of mortality in those taking the drugs, while the other two reviews found no association with mortality. Only two metaanalyses were carried out for HCQ combined with Azithromycin and both reported a 2.5-fold increase in risk of mortality. The updated meta-analyses carried out for this review showed that $\mathrm{HCQ}$, with or without Azithromycin, was not beneficial in reducing 
medRxiv preprint doi: https://doi.org/10.1101/2020.07.28.20164012; this version posted July 9, 2021. The copyright holder for this preprint (which was not certified by peer review) is the author/funder, who has granted medRxiv a license to display the preprint in perpetuity. It is made available under a CC-BY-NC-ND 4.0 International license .

the risk of mortality from COVID-19. Findings from included reviews suggested no beneficial effect of either HCQ alone or HCQ with Azithromycin on the need for intensive care services, disease exacerbation and virological cure. Our updated metaanalyses also showed that there was no beneficial effect of HCQ with or without Azithromycin on the risk of transfer to the ICU, intubation or need for mechanical ventilation, virological cure and disease exacerbation. Lastly, all the included reviews, except one, found that HCQ with or without Azithromycin increased the risk of adverse events, in agreement with our updated meta-analysis.

An important consideration in this meta-review is the impact of methodological limitations on the results of both the primary studies and the systematic reviews and meta-analyses included in this umbrella review. These limitations could primarily have resulted from the urgency of the need to find a cure, at short notice, for a pandemic that seemed to be worsening in many countries. The limitations include, but are not limited to, small study sample sizes, the scarcity of randomized controlled trials, and the lack of methodological rigueur in the primary studies. All the reviews, except one (28), included observational studies, which tend to have confounding and may lead to biased estimates of effects. An additional weakness of these observational studies is that patients and clinicians will most likely choose an experimental drug, compared to standard care which comprises of symptom management, during a pandemic with a perceived high risk of death and no cure. Faced with a life-threatening illness, patients with severe illness will likely choose the experimental drug in the absence of proven alternatives, while those with mild to moderate disease may not want the experimental drug. The inclusion of observational studies in these meta-analyses seems to have been driven by the lack of good quality experimental studies and the need to use as much of the available information as possible. The observational studies were bigger than the RCTs and therefore tended to influence the pooled estimates. The effect of inclusion of the observational studies could have been reduced by using qualityadjusted meta-analysis synthesis, which decreases the weight of the observational studies in the overall estimate. However, none of the existing meta-analyses adjusted for the quality of the included studies in their syntheses, except Shamshirian et al. 2020 (55), who carried out a sensitivity analysis with experimental studies only. Further, the 
medRxiv preprint doi: https://doi.org/10.1101/2020.07.28.20164012; this version posted July 9, 2021. The copyright holder for this preprint (which was not certified by peer review) is the author/funder, who has granted medRxiv a license to display the preprint in perpetuity. It is made available under a CC-BY-NC-ND 4.0 International license .

poor quality of studies included in the reviews is one of the limitations frequently cited by the review authors. Some major limitations in the experimental studies include the inclusion of participants who had COVID-19 diagnosed using symptoms in one study (64), controlled clinical trials which had a high risk of selection bias (66), and studies where the veracity of data presented could not be verified (71). An example of the later is a letter about 15 clinical trials in China claiming that $C Q$ was effective $(27,71)$ but without any data presented. This letter was included in two reviews $(54,57)$ and contributed to the perceived efficacy of $\mathrm{CQ}$ and $\mathrm{HCQ}$, which resulted in regulatory approvals in many countries. The risk of bias associated with a lack of either proper randomization or protection of the allocation sequence in the controlled trials is particularly serious in the case of COVID-19. This is because without an effective cure, and based on the hype about $\mathrm{CQ} / \mathrm{HCQ}$, severely ill patients were more likely to be given the experimental treatment, and consequently have worse outcomes if the treatment was not efficacious. Finally, it would be remiss to not mention that the biggest observational study included in two of the meta-analyses $(31,55)$ was subsequently retracted (27). This impacts the findings of these reviews although one of the reviews carried out a sensitivity analysis without this study.

The findings of our updated meta-analysis of experimental studies showed no benefit of $\mathrm{HCQ}$, with or without Azithromycin in reducing the risk of all-cause mortality. Our findings are in agreement with findings of two of the included meta-analyses $(54,55)$ while two other reviews $(50,52)$ found a higher risk of mortality in the HCQ arms. Of the two meta-analyses which found a higher risk of mortality, Singh et al. 2020 (50) included three studies with 474 participants from two observational studies $(72,73)$ and the one quasi-experimental study (66) had a weight of $4.6 \%$, in their meta-analysis. Yang et al. 2020 (52) included data from two small trials and one observational study, the US veterans study (72) which had a weight of $95 \%$ in the meta-analysis, and is misclassified as an RCT in the meta-analysis. Further, all the deaths, except one, occurred in the U.S. veterans' observational study, and therefore the meta-analysis effectively drew its conclusions from the one big observational study where clinical severity may have influenced allocation of treatment. Similar results were also observed by Yang et al. 2020 (52) who also included the same three studies in their meta- 
medRxiv preprint doi: https://doi.org/10.1101/2020.07.28.20164012; this version posted July 9, 2021. The copyright holder for this preprint (which was not certified by peer review) is the author/funder, who has granted medRxiv a license to display the preprint in perpetuity. It is made available under a CC-BY-NC-ND 4.0 International license .

analysis. Although Shamshirian et al. 2020 (55) found no significant difference in mortality when HCQ was used alone, they found a 2.5 fold increase in risk of mortality when the drug was combined with Azithromycin, a result similar to that of Yang et al. 2020 (52). The meta-analysis by Shamshirian et al. 2020 included several observational studies and data from the retracted study by Mehra et al. 2020, although sensitivity analyses without this study did not alter their conclusions. Charko et al. 2020 (54) included data from five observational studies and only one quasi experimental study which had a weight of $5.8 \%$ in the meta-analysis. Despite these shortcomings in the reviews, the findings from our updated meta-analysis and these existing reviews suggest that, at the very least, $\mathrm{HCQ}$ with or without Azithromycin do not have a protective effect against mortality in individuals with COVID-19 and may be harmful, in the worst-case scenario.

The findings of this review also shows that $\mathrm{HCQ}$ with or without Azithromycin does not have a beneficial effect on other clinical outcomes. Our updated meta-analyses, in agreement with most of the included reviews $(30,31,50,51,55,56)$, showed no benefit of $\mathrm{HCQ}$ with or without Azithromycin in reducing the need for intensive care services, limiting disease exacerbation or viral clearance. Lastly, in the updated metaanalysis, and in agreement with most of the included reviews, HCQ with or without Azithromycin, was associated 12-fold increase in the odds of adverse events. It should be noted however, that the occurrence of serious adverse events in the included experimental studies was rare, in agreement with the known safety profile of both $\mathrm{CQ}$ and $\mathrm{HCQ}$.

Our updated meta-analysis had limitations which include small sample sizes in seven of the eight included trials and high risk of selection bias in the included quasiexperimental study. Some of the strengths of this updated meta-analysis include the inclusion of data of individuals with confirmed COVID-19 only, the inclusion of experimental studies only and the use of quality effects models to adjust for the weight of the studies in the meta-analysis. 


\section{Conclusion}

The use of HCQ with or without Azithromycin, for treating COVID-19, does not seem to have benefit in reducing mortality or the severe sequela of COVID-19, including transfer to the ICU, intubation, mechanical ventilation, virological cure or disease exacerbation. Rather use of these drugs is associated with a higher risk of adverse events, mainly gastrointestinal such as vomiting, diarrhea, and nausea. These findings do not support any further use of either $\mathrm{CQ}$ or $\mathrm{HCQ}$, with or without Azithromycin, for the treatment of COVID-19.

\section{Author contributions}

TC - Conception and design of study, data curation (search for studies, data extraction and assessment of quality) formal analysis, software, writing original draft and revisions and final approval of submitted draft

OAHM - Data curation (search for studies, data extraction and assessment of quality), formal analysis, software, revisions and final approval of submitted draft

GH - Revisions and final approval of submitted draft

NW - Data curation (data extraction and assessment of quality), revisions and final approval of submitted draft

SB - Revisions and final approval of submitted draft

NS - Data curation (data extraction and assessment of quality), formal analysis, software, revisions and final approval of submitted draft

ATMA - Data curation (data extraction and assessment of quality), formal analysis, software, revisions and final approval of submitted draft

JTM - Data curation (search for studies), revisions and final approval of submitted draft

MME - Revisions and final approval of submitted draft

LT - Conception and design of study, formal analysis, revisions and final approval of submitted draft

SARD - Conception and design of study, data curation, formal analysis, software, revisions and final approval of submitted draft

\section{Conflict of interest}

All the authors declare no conflict of interest 


\section{Funding}

No funding to report

\section{Abbreviations}

COVID-19 - Coronavirus Disease-19

SARS-CoV-2 - severe acute respiratory syndrome coronavirus 2

$\mathrm{HCQ}$ - hydroxychloroquine,

$\mathrm{CQ}$ - chloroquine

PRIO-harms - Preferred Reporting Items for Overviews of Systematic Reviews including harms checklist

AMSTAR - Assessing the Methodological Quality of Systematic Reviews

MASTER - MethodologicAI STandard for Epidemiological Research

PRISMA - Preferred Reporting Items for Systematic Review and Meta-Analysis

CDSR - Cochrane Database of Systematic Reviews

CENTRAL - Cochrane Central Register of Controlled Trials

DARE - Database of Abstracts of Reviews of Effectiveness

\section{References}

1. Zhou F, Yu T, Du R, Fan G, Liu Y, Liu Z, et al. Clinical course and risk factors for mortality of adult inpatients with COVID-19 in Wuhan, China: a retrospective cohort study. Lancet (London, England). 2020;395(10229):1054-62.

2. World Health Organization. WHO Coronavirus (COVID-19) Dashboard 2021 [updated 2 July 2021. Available from: https://covid19.who.int/.

3. Edmunds WJ. Finding a path to reopen schools during the COVID-19 pandemic. Lancet Child Adolesc Health. 2020;4(11):796-7.

4. Torjesen I. Covid-19: England plan to ease lockdown is "confusing" and "risky," say doctors. BMJ (Clinical research ed). 2020;369:m1877.

5. Tyagi K, Ghosh A, Nair D, Dutta K, Singh Bhandari P, Ahmed Ansari I, et al. Breakthrough COVID19 infections after vaccinations in healthcare and other workers in a chronic care medical facility in New Delhi, India. Diabetes \& metabolic syndrome. 2021;15(3):1007-8. 
6. Sahraei Z, Shabani M, Shokouhi S, Saffaei A. Aminoquinolines against coronavirus disease 2019 (COVID-19): chloroquine or hydroxychloroquine. Int J Antimicrob Agents. 2020;105945(10.1016).

7. Yazdany J, Kim AHJ. Use of Hydroxychloroquine and Chloroquine During the COVID-19 Pandemic: What Every Clinician Should Know. Ann Intern Med. 2020;172(11):754-5.

8. Zhou D, Dai SM, Tong Q. COVID-19: a recommendation to examine the effect of hydroxychloroquine in preventing infection and progression. J Antimicrob Chemother. 2020;75(7):1667-70.

9. Graham RL, Donaldson EF, Baric RS. A decade after SARS: strategies for controlling emerging coronaviruses. Nature Reviews Microbiology. 2013;11(12):836-48.

10. Yao X, Ye F, Zhang M, Cui C, Huang B, Niu P, et al. In Vitro Antiviral Activity and Projection of Optimized Dosing Design of Hydroxychloroquine for the Treatment of Severe Acute Respiratory Syndrome Coronavirus 2 (SARS-CoV-2). Clin Infect Dis. 2020;71(15):732-9.

11. Wong YK, Yang J, He Y. Caution and clarity required in the use of chloroquine for COVID-19. The Lancet Rheumatology. 2020;2(5):e255.

12. Wang M, Cao R, Zhang L, Yang X, Liu J, Xu M, et al. Remdesivir and chloroquine effectively inhibit the recently emerged novel coronavirus (2019-nCoV) in vitro. Cell research. 2020;30(3):269-71.

13. Gautret P, Lagier JC, Parola P, Hoang VT, Meddeb L, Sevestre J, et al. Clinical and microbiological effect of a combination of hydroxychloroquine and azithromycin in 80 COVID-19 patients with at least a six-day follow up: A pilot observational study. Travel Med Infect Dis. 2020;34:101663.

14. Devaux CA, Rolain J-M, Colson P, Raoult D. New insights on the antiviral effects of chloroquine against coronavirus: what to expect for COVID-19? International Journal of Antimicrobial Agents. 2020;55(5):105938.

15. Lenzer J. Covid-19: US gives emergency approval to hydroxychloroquine despite lack of evidence. BMJ (Clinical research ed). 2020;369:m1335.

16. Nicastri E, Petrosillo N, Bartoli TA, Lepore L, Mondi A, Palmieri F, et al. National institute for the infectious diseases "L. Spallanzani", IRCCS. Recommendations for COVID-19 clinical management. Infectious Disease Reports. 2020;12(1).

17. Gao J, Tian Z, Yang X. Breakthrough: Chloroquine phosphate has shown apparent efficacy in treatment of COVID-19 associated pneumonia in clinical studies. Biosci Trends. 2020;14(1):72-3. 
medRxiv preprint doi: https://doi.org/10.1101/2020.07.28.20164012; this version posted July 9, 2021. The copyright holder for this preprint (which was not certified by peer review) is the author/funder, who has granted medRxiv a license to display the preprint in perpetuity. It is made available under a CC-BY-NC-ND 4.0 International license .

18. Million M, Lagier JC, Gautret P, Colson P, Fournier PE, Amrane S, et al. Early treatment of COVID-19 patients with hydroxychloroquine and azithromycin: A retrospective analysis of 1061 cases in Marseille, France. Travel Med Infect Dis. 2020;35:101738.

19. Molina JM, Delaugerre C, Le Goff J, Mela-Lima B, Ponscarme D, Goldwirt L, et al. No evidence of rapid antiviral clearance or clinical benefit with the combination of hydroxychloroquine and azithromycin in patients with severe COVID-19 infection. Med Mal Infect. 2020;10.

20. Gautret P, Lagier J-C, Parola P, Meddeb L, Mailhe M, Doudier B, et al. Hydroxychloroquine and azithromycin as a treatment of COVID-19: results of an open-label non-randomized clinical trial. International journal of antimicrobial agents. 2020:105949.

21. Rosenberg ES, Dufort EM, Udo T, Wilberschied LA, Kumar J, Tesoriero J, et al. Association of Treatment With Hydroxychloroquine or Azithromycin With In-Hospital Mortality in Patients With COVID-19 in New York State. Jama. 2020;323(24):2493-502.

22. Chen J, Liu D, Liu L, Liu P, Xu Q, Xia L, et al. A pilot study of hydroxychloroquine in treatment of patients with moderate COVID-19. Zhejiang da xue xue bao Yi xue ban = Journal of Zhejiang University Medical sciences. 2020;49(2):215-9.

23. Jankelson L, Karam G, Becker ML, Chinitz LA, Tsai MC. QT prolongation, torsades de pointes, and sudden death with short courses of chloroquine or hydroxychloroquine as used in COVID-19: A systematic review. Heart Rhythm. 2020;17(9):1472-9.

24. Horby P, Mafham M, Linsell L, Bell JL, Staplin N, Emberson JR, et al. Effect of Hydroxychloroquine in Hospitalized Patients with COVID-19: Preliminary results from a multicentre, randomized, controlled trial. medRxiv. 2020:2020.07.15.20151852.

25. Ader F. Protocol for the DisCoVeRy trial: multicentre, adaptive, randomised trial of the safety and efficacy of treatments for COVID-19 in hospitalised adults. BMJ open. 2020;10(9):e041437.

26. World Health Organisation. Q\&A : Hydroxychloroquine and COVID-19 2020 [Available from: https://www.who.int/news-room/q-a-detail/q-a-hydroxychloroquine-and-covid-19\#.

27. Mehra MR, Desai SS, Ruschitzka F, Patel AN. RETRACTED: Hydroxychloroquine or chloroquine with or without a macrolide for treatment of COVID-19: a multinational registry analysis. Lancet. 2020 May 22:S0140-6736(20)31180-6. doi: 10.1016/S0140-6736(20)31180-6. Epub ahead of print. Retraction in: Lancet. 2020 Jun 5;:null. Erratum in: Lancet. 2020 May 30;: PMID: 32450107; PMCID: PMC7255293. 
medRxiv preprint doi: https://doi.org/10.1101/2020.07.28.20164012; this version posted July 9, 2021. The copyright holder for this preprint (which was not certified by peer review) is the author/funder, who has granted medRxiv a license to display the preprint in perpetuity. It is made available under a CC-BY-NC-ND 4.0 International license .

28. Chowdhury MS, Rathod J, Gernsheimer J. A Rapid Systematic Review of Clinical Trials Utilizing Chloroquine and Hydroxychloroquine as a Treatment for COVID-19. Acad Emerg Med. 2020;27(6):493-504.

29. Gbinigie K, Frie K. Should chloroquine and hydroxychloroquine be used to treat COVID19? A rapid review. BJGP Open. 2020;4(2).

30. Hernandez AV, Roman YM, Pasupuleti V, Barboza JJ, White CM. Hydroxychloroquine or Chloroquine for Treatment or Prophylaxis of COVID-19: A Living Systematic Review. Ann Intern Med. 2020;173(4):287-96.

31. Takla M, Jeevaratnam K. Chloroquine, hydroxychloroquine, and COVID-19: Systematic review and narrative synthesis of efficacy and safety. Saudi Pharm J. 2020;28(12):1760-76.

32. Singh AK, Singh A, Shaikh A, Singh R, Misra A. Chloroquine and hydroxychloroquine in the treatment of COVID-19 with or without diabetes: A systematic search and a narrative review with a special reference to India and other developing countries. Diabetes \& metabolic syndrome. 2020;14(3):241-6.

33. Bougioukas KI, Liakos A, Tsapas A, Ntzani E, Haidich AB. Preferred reporting items for overviews of systematic reviews including harms checklist: a pilot tool to be used for balanced reporting of benefits and harms. Journal of clinical epidemiology. 2018;93:9-24.

34. Page MJ, McKenzie JE, Bossuyt PM, Boutron I, Hoffmann TC, Mulrow CD, et al. The PRISMA 2020 statement: An updated guideline for reporting systematic reviews. International journal of surgery (London, England). 2021;88:105906.

35. Struyf T, Deeks JJ, Dinnes J, Takwoingi Y, Davenport C, Leeflang MM, et al. Signs and symptoms to determine if a patient presenting in primary care or hospital outpatient settings has COVID-19 disease. Cochrane Database Syst Rev. 2020;7(7):Cd013665.

36. Shea BJ, Hamel C, Wells GA, Bouter LM, Kristjansson E, Grimshaw J, et al. AMSTAR is a reliable and valid measurement tool to assess the methodological quality of systematic reviews. Journal of clinical epidemiology. 2009;62(10):1013-20.

37. Stone JC, Glass K, Clark J, Ritskes-Hoitinga M, Munn Z, Tugwell P, et al. The MethodologicAI STandards for Epidemiological Research (MASTER) scale demonstrated a unified framework for bias assessment. Journal of clinical epidemiology. 2021;134:52-64.

38. Stone JC, Glass K, Clark J, Munn Z, Tugwell P, Doi SA. A unified framework for bias assessment in clinical research. International Journal of Evidence-Based Healthcare. 2019;17(2):106-20.

39. McKenzie JE, Brennan SE. Synthesizing and presenting findings using other methods. Cochrane Handbook for Systematic Reviews of Interventions. 2019:321-47. 
medRxiv preprint doi: https://doi.org/10.1101/2020.07.28.20164012; this version posted July 9, 2021. The copyright holder for this preprint (which was not certified by peer review) is the author/funder, who has granted medRxiv a license to display the preprint in perpetuity. It is made available under a CC-BY-NC-ND 4.0 International license .

40. R Core Team (2019). R: A language and environment for statistical computing. $R$ Foundation for Statistical Computing. Vienna, Austria: R Foundation for Statistical Computing; 2019.

41. Tableau Foundation. Tableau Software 2020 [Available from:

\section{https://www.tableau.com/foundation.}

42. Doi SA, Barendregt JJ, Khan S, Thalib L, Williams GM. Advances in the meta-analysis of heterogeneous clinical trials I: the inverse variance heterogeneity model. Contemporary clinical trials. 2015;45:130-8.

43. Furuya-Kanamori L, Thalib L, Barendregt JJ. Meta-analysis in evidence-based healthcare: a paradigm shift away from random effects is overdue. International Journal of Evidence-Based Healthcare. 2017;15(4):152-60.

44. Stata Press. Stata Statistical Software. Stata Corporation, College Station,2016.

45. Doi SA, Furuya-Kanamori L, Xu C, Lin L, Chivese T, Thalib L. Questionable utility of the relative risk in clinical research: a call for change to practice. J Clin Epidemiol. 2020 Nov 7:S0895-4356(20)31171-9. doi: 10.1016/j.jclinepi.2020.08.019. Epub ahead of print. PMID: 33171273.

46. Higgins JP, Thompson SG, Deeks JJ, Altman DG. Measuring inconsistency in metaanalyses. BMJ (Clinical research ed). 2003;327(7414):557-60.

47. Furuya-Kanamori L, Barendregt JJ, Doi SA. A new improved graphical and quantitative method for detecting bias in meta-analysis. International journal of evidence-based healthcare. 2018;16(4):195-203.

48. Terrin N, Schmid CH, Lau J. In an empirical evaluation of the funnel plot, researchers could not visually identify publication bias. Journal of clinical epidemiology. 2005;58(9):894-901. 49. Sarma P, Kaur H, Kumar H, Mahendru D, Avti P, Bhattacharyya A, et al. Virological and clinical cure in COVID-19 patients treated with hydroxychloroquine: A systematic review and meta-analysis. J Med Virol. 2020;92(7):776-85.

50. Singh AK, Singh A, Singh R, Misra A. "Hydroxychloroquine in patients with COVID-19: A Systematic Review and meta-analysis.". Diabetes \& metabolic syndrome. 2020;14(4):589-96. 51. Suranagi UD, Rehan HS, Goyal N. Review of Current Evidence of Hydroxychloroquine in Pharmacotherapy of COVID-19. medRxiv. 2020:2020.04.16.20068205.

52. Yang TH, Chou CY, Yang YF, Chien CS, Yarmishyn AA, Yang TY, et al. Systematic review and meta-analysis of the effectiveness and safety of hydroxychloroquine in treating COVID-19 patients. J Chin Med Assoc. 2021;84(2):233-41. 
53. Rodrigo C, Fernando SD, Rajapakse S. Clinical evidence for repurposing chloroquine and hydroxychloroquine as antiviral agents: a systematic review. Clin Microbiol Infect. 2020;26(8):979-87.

54. Chacko J, Brar G, Premkumar R. Hydroxychloroquine in COVID-19: An updated systematic review with meta-analysis. medRxiv. 2020:2020.05.14.20101774.

55. Shamshirian A, Hessami A, Heydari K, Navaei RA, Ebrahimzadeh MA, Yip GW, et al. The Role of Hydroxychloroquine in COVID-19: A Systematic Review and Meta-Analysis. Ann Acad Med Singap. 2020;49(10):789-800.

56. Das S, Bhowmick S, Tiwari S, Sen S. An Updated Systematic Review of the Therapeutic Role of Hydroxychloroquine in Coronavirus Disease-19 (COVID-19). Clin Drug Investig. 2020;40(7):591-601.

57. Wang Y, Liang S, Qiu T, Han R, Dabbous M, Nowotarska A, et al. Rapid systematic review on clinical evidence of chloroquine and hydroxychloroquine in COVID-19: critical assessment and recommendation for future clinical trials. medRxiv. 2020:2020.06.01.20118901. 58. Huang M, Tang T, Pang P, Li M, Ma R, Lu J, et al. Treating COVID-19 with Chloroquine. J Mol Cell Biol. 2020;12(4):322-5.

59. Tang W, Cao Z, Han M, Wang Z, Chen J, Sun W, et al. Hydroxychloroquine in patients with mainly mild to moderate coronavirus disease 2019: open label, randomised controlled trial. BMJ (Clinical research ed). 2020;369:m1849.

60. Chen Z, Hu J, Zhang Z, Jiang S, Han S, Yan D, et al. Efficacy of hydroxychloroquine in patients with COVID-19: results of a randomized clinical trial. medRxiv. 2020:2020.03.22.20040758.

61. Okour M, Al-Kofahi M, Austin D. Hydroxychloroquine and azithromycin as potential treatments for COVID-19; clinical status impacts the outcome. J Pharmacokinet Pharmacodyn. 2020;47(3):187-8.

62. Jiang S. Treatment plan of chloroquine phosphate in Guangdong Province. The respiratory department of Sun Yat Sen Memorial Hospital of Sun Yat sen University. 2020. (Source not known)

63. Borba MGS, Val FFA, Sampaio VS, Alexandre MAA, Melo GC, Brito M, et al. Effect of High vs Low Doses of Chloroquine Diphosphate as Adjunctive Therapy for Patients Hospitalized With Severe Acute Respiratory Syndrome Coronavirus 2 (SARS-CoV-2) Infection: A Randomized Clinical Trial. JAMA Network Open. 2020;3(4):e208857-e.

64. Esper RB, da Silva RS, Oikawa FT, Castro MM, Razuk-Filho A, Batista PB, Lotze SM, da Rocha CN, de Sá Cunha Filho R, de Oliveira SE, Ribeiro PL. Empirical treatment with 
medRxiv preprint doi: https://doi.org/10.1101/2020.07.28.20164012; this version posted July 9, 2021. The copyright holder for this preprint (which was not certified by peer review) is the author/funder, who has granted medRxiv a license to display the preprint in perpetuity. It is made available under a CC-BY-NC-ND 4.0 International license .

hydroxychloroquine and azithromycin for suspected cases of COVID-19 followed-up by telemedicine. Prevent Senior Institute SP, Brazil, ed. São Paulo. 2020 Jul 28;25. Available at http://blog.couvelard.com/herve/files/etude_bresil.pdf

65. Gao J, Tian Z, Yang X. Breakthrough: Chloroquine phosphate has shown apparent efficacy in treatment of COVID-19 associated pneumonia in clinical studies. Bioscience trends. 2020. Available at https://www.jstage.jst.go.jp/article/bst/advpub/0/advpub_2020.01047/_pdf 66. Barbosa J, Kaitis D, Freedman R, Le K, Lin X. Clinical outcomes of hydroxychloroquine in hospitalized patients with COVID-19: a quasi-randomized comparative study. 2020. (Paper shared on the internet as an NEJM journal submission proof. Publication status not known) 67. Chen CP, Lin YC, Chen TC, Tseng TY, Wong HL, Kuo CY, et al. A multicenter, randomized, open-label, controlled trial to evaluate the efficacy and tolerability of hydroxychloroquine and a retrospective study in adult patients with mild to moderate coronavirus disease 2019 (COVID-19). PloS one. 2020;15(12):e0242763.

68. Mitjà $\mathrm{O}$, Corbacho-Monné $\mathrm{M}$, Ubals $\mathrm{M}$, Tebe $\mathrm{C}$, Peñafiel $\mathrm{J}$, Tobias $\mathrm{A}$, et al. Hydroxychloroquine for Early Treatment of Adults with Mild Covid-19: A Randomized-Controlled Trial. Clin Infect Dis. 2020. Clin Infect Dis. 2020 Jul 16:ciaa1009. doi: 10.1093/cid/ciaa1009. Epub ahead of print. PMID: 32674126; PMCID: PMC7454406.

69. Cavalcanti AB, Zampieri FG, Rosa RG, Azevedo LCP, Veiga VC, Avezum A, et al. Hydroxychloroquine with or without Azithromycin in Mild-to-Moderate Covid-19. The New England journal of medicine. 2020;383(21):2041-52.

70. Skipper CP, Pastick KA, Engen NW, Bangdiwala AS, Abassi M, Lofgren SM, et al. Hydroxychloroquine in Nonhospitalized Adults With Early COVID-19 : A Randomized Trial. Ann Intern Med. 2020;173(8):623-31.

71. Gao J, Tian Z, Yang X. Breakthrough: Chloroquine phosphate has shown apparent efficacy in treatment of COVID-19 associated pneumonia in clinical studies. BioScience Trends. 2020;14(1):72-3.

72. Magagnoli J, Narendran S, Pereira F, Cummings TH, Hardin JW, Sutton SS, Ambati J. Outcomes of Hydroxychloroquine Usage in United States Veterans Hospitalized with COVID-19. Med (N Y). 2020 Dec 18;1(1):114-127.e3. doi: 10.1016/j.medj.2020.06.001. Epub 2020 Jun 5. PMID: 32838355; PMCID: PMC7274588.

73. Mahévas M, Tran VT, Roumier M, Chabrol A, Paule R, Guillaud C, et al. Clinical efficacy of hydroxychloroquine in patients with covid-19 pneumonia who require oxygen: observational comparative study using routine care data. BMJ (Clinical research ed). 2020;369:m1844. 
medRxiv preprint doi: https://doi.org/10.1101/2020.07.28.20164012; this version posted July 9, 2021. The copyright holder for this preprint (which was not certified by peer review) is the author/funder, who has granted medRxiv a license to display the preprint in perpetuity. It is made available under a CC-BY-NC-ND 4.0 International license. 